\title{
Isoforms of $\mathrm{Na}, \mathrm{K}-\mathrm{ATPase} \alpha$ and $\beta$ Subunits in the Rat Cerebellum and in Granule Cell Cultures
}

\author{
Liang Peng, ${ }^{1}$ Pablo Martin-Vasallo, ${ }^{2}$ and Kathleen J. Sweadner ${ }^{1}$ \\ 1 Laboratory of Membrane Biology, Neuroscience Center, Massachusetts General Hospital, Charlestown, Massachusetts \\ 02129, and 'Laboratorio de Biologia del Desarrollo, Departamento de Bioquimica y Biologia Molecular, Universidad de La \\ Laguna, 38206 La Laguna, Tenerife, Spain
}

There are multiple isoforms of the Na,K-ATPase in the nervous system, three isoforms of the $\alpha$ subunit, and at least two of the $\beta$ subunit. The $\alpha$ subunit is the catalytic subunit. The $\beta$ subunit has several roles. It is required for enzyme assembly, it has been implicated in neuron-glia adhesion, and the experimental exchange of $\beta$ subunit isoforms modifies enzyme kinetics, implying that it affects functional properties. Here we describe the specificities of antibodies against the Na,K-ATPase $\beta$ subunit isoforms $\beta 1$ and $\beta 2$. These antibodies, along with antibodies against the $\alpha$ subunit isoforms, were used to stain sections of the rat cerebellum and cultures of cerebellar granule cells to ascertain expression and subcellular distribution in identifiable cells. Comparison of $\alpha$ and $\beta$ isoform distribution with doublelabel staining demonstrated that there was no preferential as- sociation of particular $\alpha$ subunits with particular $\beta$ subunits, nor was there an association with excitatory or inhibitory neurotransmission modes. Isoform composition differences were seen when Purkinje, basket, and granule cells were compared. Whether $\beta 1$ and $\beta 2$ are specific for neurons and glia, respectively, has been controversial, but expression of both $\beta$ subunit types was seen here in granule cells. In rat cerebellar astrocytes, in sections and in culture, $\alpha 2$ expression was prominent, yet the expression of either $\beta$ subunit was low in comparison. The complexity of $\mathrm{Na}, \mathrm{K}-\mathrm{ATPase}$ isoform distribution underscores the subtlety of its regulation and physiological role in excitable cells.

Key words: Na,K-ATPase; cerebellum; isoform localization; ion transport; granule cell; astrocyte; Purkinje cell; basket cell
The Na,K-ATPase (sodium and potassium ion-exchanging adenosine triphosphatase) is composed of two different kinds of subunits, $\alpha$ and $\beta$. Differences in kinetic properties between isoforms have implications for $\mathrm{Na}^{+}$and $\mathrm{K}^{+}$transport rates and hence for cellular excitability and $\mathrm{Na}^{+}$-dependent neurotransmitter uptake. The three $\alpha$ isoforms have shown significantly different affinities for $\mathrm{Na}^{+}$and $\mathrm{K}^{+}$when expressed as transfectants in HeLa cells (Jewell and Lingrel, 1991; Daly et al., 1994) and in different tissues (Sun and Ball, 1992; Therien et al., 1996). When the two $\beta$ subunits are paired with the same $\alpha$ subunit, they also cause differences in $\mathrm{Na}^{+}$and $\mathrm{K}^{+}$affinity and $\alpha-\beta$ complex stability (Jaisser et al., 1992; Schmalzing et al., 1992; Eakle et al., 1994; Blanco et al., 1995). The $\beta 2$ subunit [also called adhesion molecule on glia (AMOG)] has been implicated as a receptor target in neuron-glia adhesion as well (Gloor et al., 1990; Müller-Husmann et al., 1993).

Immunocytochemical localization of the $\alpha$ isoforms in CNS has been reported (McGrail et al., 1991), but not localization of the $\beta$ isoforms. In situ hybridization with isoform-specific probes and immunocytochemistry with isoform-specific antibodies have revealed both cell-type specificity in the nervous system and sometimes the coexistence of different isoforms in the same cell.

Received Feb. 12, 1997; accepted March 4, 1997.

This work was supported by National Institutes of Health Grant NS 27653 to K.J.S and by a fellowship from the Medical Research Council of Canada to L.P. We are grateful to Drs. James Gurd (University of Toronto, Toronto, Ontario, Canada) and Phillip Beesley (Royal Holloway and Bedford New College, Egham, Surrey, UK) for antibody mAb SM-GP50; to Dr. Andrea Quaroni, Cornell University, for antibody IEC 1/48; and to Dr. W. James Ball Jr., University of Cincinnati, for antiserum $757 \beta$

Correspondence should be addressed to Dr. Kathleen Sweadner, 149-6118 Neuroscience Center, Massachusetts General Hospital, 149 13th Street, Charlestown, MA 02129.

Copyright (C) 1997 Society for Neuroscience $\quad 0270-6474 / 97 / 173488-15 \$ 05.00 / 0$
Although in situ hybridization gives unambiguous positive identification in large neuronal somas, interpretation is limited when label is light or diffusely distributed, and this has given rise to controversies about the cell specificity of Na,K-ATPase isoforms. For example, some neurons express $\alpha 3$, but evidence for $\alpha 3$ mRNA in the granule cell layer (Schneider et al., 1988; Brines et al., 1991; Hieber et al., 1991; Watts et al., 1991) was not accompanied by unambiguous localization of the protein (McGrail et al., 1991; Cameron et al., 1994). The question is whether this neuron expresses principally $\alpha 1$ or whether it sequesters $\alpha 3$ in its axons. Bergmann glia have been proposed to express $\beta 2$ and to use it as an adhesion protein during development (Antonicek et al., 1987), and mRNA hybridizing with $\beta 2$ and $\alpha 1$ probes has been detected between Purkinje neurons where the Bergmann glia cell bodies lie (Pagliusi et al., 1990; Watts et al., 1991; Magyar et al., 1994), but detection of the $\beta 2$ protein in Bergmann glial processes has been demonstrated only in postnatal day 6 (P6) animals (Antonicek et al., 1987). It has been asserted that $\beta 2$ is expressed primarily in astrocytes in the cerebellar granular layer in adult mice (Antonicek et al., 1987), but in contrast, an antibody now known to react with $\beta 2$ was reported to stain rat cerebellar neurons exclusively (Beesley et al., 1987). These and similar issues were examined here by immunocytochemical analysis of sections and of granule cells and astrocytes in cell culture.

At the outset of this work, questions had arisen about three anti-Na,K-ATPase antibodies that needed to be settled before they were used as isoform-specific probes. A monoclonal antibody $(\mathrm{mAb})$ originally described as specific for $\alpha 3$ in the rat did not recognize authentic $\alpha 3$ in the heart; a new $\alpha 3$-specific antibody was used here. Two mAbs that have been shown to recognize $\beta 1$ and $\beta 2$, respectively, needed to be checked for cross-reactivity. By 


\begin{tabular}{|c|c|c|c|}
\hline Isoform & Type & Name & Reference \\
\hline$\alpha 1$ & Monoclonal & McK1 & $\begin{array}{l}\text { (Felsenfeld and Sweadner, 1988; } \\
\text { Arystarkhova and Sweadner, 1996) }\end{array}$ \\
\hline$\alpha 2$ & Monoclonal & $\mathrm{McB} 2$ & (Urayama et al., 1989) \\
\hline$\alpha 3$ & Monoclonal & XVIF9-G10 & (Arystarkhova and Sweadner, 1996) \\
\hline$\beta 1$ & Monoclonal & IEC $1 / 48$ & (Marxer et al., 1989) \\
\hline$\beta 1$ & Polyclonal & SpETb1 & (Gonzalez-Martinez et al., 1994) \\
\hline$\beta 2$ & Monoclonal & SM-GP50 & (Beesley et al., 1986, 1987) \\
\hline$\beta 2$ & Polyclonal & $\mathrm{SpETb} 2$ & (Gonzalez-Martinez et al., 1994) \\
\hline
\end{tabular}

characterizing the antibodies and comparing their reactivities by immunofluorescence, we have been able to resolve these issues, arriving at a consensus for the distribution of $\mathrm{Na}, \mathrm{K}$-ATPase isoforms in the rat cerebellum as seen with the light microscope.

A third isoform of $\mathrm{Na}, \mathrm{K}$-ATPase $\beta$ subunit, $\beta 3$, has been reported recently (Malik et al., 1996; GenBank U51478, D84450, D84448, U59761). Our preliminary results with an isoformspecific antibody against $\beta 3$ indicated that it is present in cerebellum, but at a relatively low level. Thus this isoform was not considered in depth here.

\section{MATERIALS AND METHODS}

\section{Gel electrophoresis and immunoblotting}

Gel electrophoresis and electrophoretic blotting to nitrocellulose was performed as described previously with slab gels of 7.5 or $10 \%$ polyacrylamide and Laemmli buffers (Felsenfeld and Sweadner, 1988). Blots were quenched with $0.5 \%$ Tween 20 , stained with primary antibody for $1 \mathrm{hr}$ at room temperature, washed three times, stained with goat-anti-mouse or goat-anti-rabbit HRP-conjugated secondary antibody (Sigma, St. Louis, MO, or Accurate Chemical and Scientific, Westbury, NY) for $1 \mathrm{hr}$, and washed again. Staining was visualized with luminol reagents (Pierce Chemical, Rockford, IL), followed by exposure to Kodak XAR-5 film.

Rat brain microsomes isolated by differential centrifugation (Sweadner, 1988) were used as a positive control for all antibodies at $3 \mu \mathrm{g} / \mathrm{lane}$. Rat kidney microsomes (Jørgensen, 1974) were used as a positive control for antibodies against $\alpha 1$ and $\beta 1$ at $1 \mu \mathrm{g} /$ lane. For assessing the specificity of anti- $\beta$ antibodies, the same truncated human $\beta 1$ and $\beta 2$ proteins used for immunization were used for Western blots at 33-100 ng/lane.

\section{Antibodies used}

The epitope and isoform specificity were determined for each of the antibodies used here (Table 1).

$\alpha$ antibodies. The antibody specific for $\alpha 1, \mathrm{McK} 1$, was mapped to the sequence DKKSKK near the N terminus (Felsenfeld and Sweadner, 1988), as confirmed recently with $\alpha 1-\alpha 2$ chimeras (Arystarkhova and Sweadner, 1996). McK1 is a mouse IgG1 raised against purified rat kidney Na,K-ATPase (Felsenfeld and Sweadner, 1988). The antibody specific for $\alpha 2$, McB2, was mapped to the sequence GREYSPAATTAENG near the $\mathrm{N}$ terminus by binding to a $\lambda \mathrm{gt} 11$ expression library of $\alpha 2$ fragments (T. Pacholczyk and K. J. Sweadner, unpublished data). $\mathrm{McB} 2$ is a mouse IgG1 raised against rat brain axolemma Na,K-ATPase (Urayama et al., 1989). The antibody specific for $\alpha 3$, XVIF9-G10 ("16-F9-G10"), is a mouse IgG1 raised against canine cardiac membranes in the laboratory of Dr. Kevin Campbell, University of Iowa (now available from Affinity BioReagents, Golden, $\mathrm{CO}$ ). It is specific for $\alpha 3$, but like McK1 and McB2 it recognizes a sequence close to the $\mathrm{N}$ terminus (Arystarkhova and Sweadner, 1996). In our previous study on cerebellum we used $\mathrm{mAb} \mathrm{McBX} 3$, which is now known to recognize a post-translational modification found on $\alpha 3$ in the rat brain (Arystarkhova and Sweadner, 1996). Antibodies XVIF9-G10 and McBX3 gave indistinguishable staining patterns in the rat retina (Arystarkhova and Sweadner, 1996).

$\beta$ antibodies. IEC $1 / 48$ is a mouse $\operatorname{IgG} 1$ raised against cultured crypt cells from the small intestine of the rat and shown to react with $\beta 1$ (Marxer et al., 1989). It was the generous gift of Dr. Andrea Quaroni (Cornell University, Ithaca, NY). IEC $1 / 48$ did not work on blots but stained fixed tissue well. A peptide-directed antibody against the first 12 amino acids of $\beta 1$, antiserum 757, was the generous gift of Dr. W. James Ball Jr. (University of Cincinnati) and was used for blots (Sun and Ball, 1992). mAb SM-GP50 is a mouse IgG1 raised against a concanavalin A-binding fraction of proteins from rat brain synaptosomal plasma membrane (Beesley et al., 1986, 1987) (the generous gift of Dr. James Gurd, University of Toronto, and Dr. Phillip Beesley, Royal Holloway and Bedford New College, Egham, UK). mAb SM-GP50 has been shown to react with recombinant mouse $\beta 2$ extracellular domain secreted from Chinese Hamster Ovary cells (Gloor et al., 1992); it worked well on blots and weakly on fixed tissue. Two polyclonal antibodies were raised against truncated proteins expressed in Escherichia coli encompassing the entire extracellular portions of human $\beta 1$ or $\beta 2$ (Gonzalez-Martinez et al., 1994); these are called SpETb1 and SpETb2, and both were used for staining fixed tissue and blots.

\section{Immunofluorescence in sections}

Fresh cerebellum was dissected, sliced into pieces no more than $3 \mathrm{~mm}$ thick, and fixed by immersion for $1 \mathrm{hr}$, followed by washing in Dulbecco's PBS for 1-4 hr and soaking in 30\% sucrose overnight. In pilot experiments, fixation with $100 \%$ methanol and with periodate-lysine-paraformaldehyde were compared for all of the antibodies. For the majority of antibodies, fixation with methanol gave better immunoreactivity, and this is the method used for all of the examples shown. Sucrose-impregnated pieces were embedded in Tissue-Tek and frozen in liquid nitrogen, and cryostat sections of $6-12 \mu \mathrm{m}$ thickness were cut. Sections were dried at room temperature and stored desiccated at $-20^{\circ} \mathrm{C}$ until use.

Sections were permeabilized by treatment with Dulbecco's PBS with $5 \%$ goat serum and $0.3 \%$ Triton $\mathrm{X}-100$ for $30 \mathrm{~min}$. Subsequent incubations were in the same buffer with either $0.1 \%$ or no Triton X-100, and incubations with either primary or secondary antibody were performed for $1 \mathrm{hr}$ at room temperature, followed by three washes with buffer with Triton X-100. All of the mAbs were used as cell culture supernatants, at dilutions of $1: 2$ to $1: 10$. Secondary antibodies were $\mathrm{F}(\mathrm{ab})_{2}$ fragments, FITC-, or tetramethylrhodamine isothiocyanate-conjugated goat-antimouse or rabbit IgG (Accurate Chemical and Scientific).

\section{Immunofluorescence in granule cell cultures}

Rat cerebellar granule cell cultures were prepared from 7-d-old rats as described previously (Peng et al., 1991). Briefly, after removal of meninges the tissue was cut into $0.4 \mathrm{~mm}$ cubes, incubated with trypsin for $2 \mathrm{~min}$ in a calcium and magnesium-free Dulbecco's PBS, centrifuged for $2 \mathrm{~min}$, reintroduced into tissue culture medium, and passed through a nylon mesh with a pore size of $75 \mu \mathrm{m}$ (Falcon cell strainer). Cells were seeded in polylysine-coated $35 \mathrm{~mm}$ Falcon tissue culture dishes or on polylysinecoated glass coverslips in $35 \mathrm{~mm}$ dishes, using half a cerebellum per dish. Cultures were maintained for $7-8 \mathrm{~d}$ in a modified DMEM $[24.5 \mathrm{mM} \mathrm{KCl}$, $30 \mathrm{~mm}$ glucose, $0.8 \mathrm{~mm}$ glutamine, and $7 \%$ horse serum (Hyclone, Logan UT)]. For some cultures, cytosine arabinoside was added to a final concentration of $40 \mu \mathrm{M}$ within $2 \mathrm{~d}$ of plating to inhibit the growth of dividing cells and reduce the number of astrocytes.

Cultures were washed with Dulbecco's PBS and fixed with $100 \%$ methanol for $6 \mathrm{~min}$ at $-20^{\circ} \mathrm{C}$. They were then washed with the same buffer and left at $4^{\circ} \mathrm{C}$ at least overnight before staining. Staining was substantially by the same procedures used for sections. Polyclonal and mAbs against glial fibrillary acidic protein (GFAP; an intermediate filament characteristic of astrocytes) were obtained from Sigma for double-labeling.

\section{RESULTS}

\section{Antibody specificity}

$\mathrm{Na}, \mathrm{K}$-ATPase $\beta$ subunit antibodies from several sources were evaluated for their isoform specificity. To determine whether each antibody reacted exclusively with a single isoform, they were tested for binding to truncated human $\beta 1$ and $\beta 2$ proteins as described previously (Gonzalez-Martinez et al., 1994). Rat brain and kidney microsomes were used as controls for antibody reactivity. Figure 1 shows the results from the antibodies that worked on Western blots. The polyclonal antibody against $\beta 1$, SpETb1, reacted well with the $\beta 1$ truncated protein and not at all with the $\beta 2$ truncated protein, whereas it reacted with $\beta$ subunits in both brain and kidney microsomes. The difference in apparent molec- 

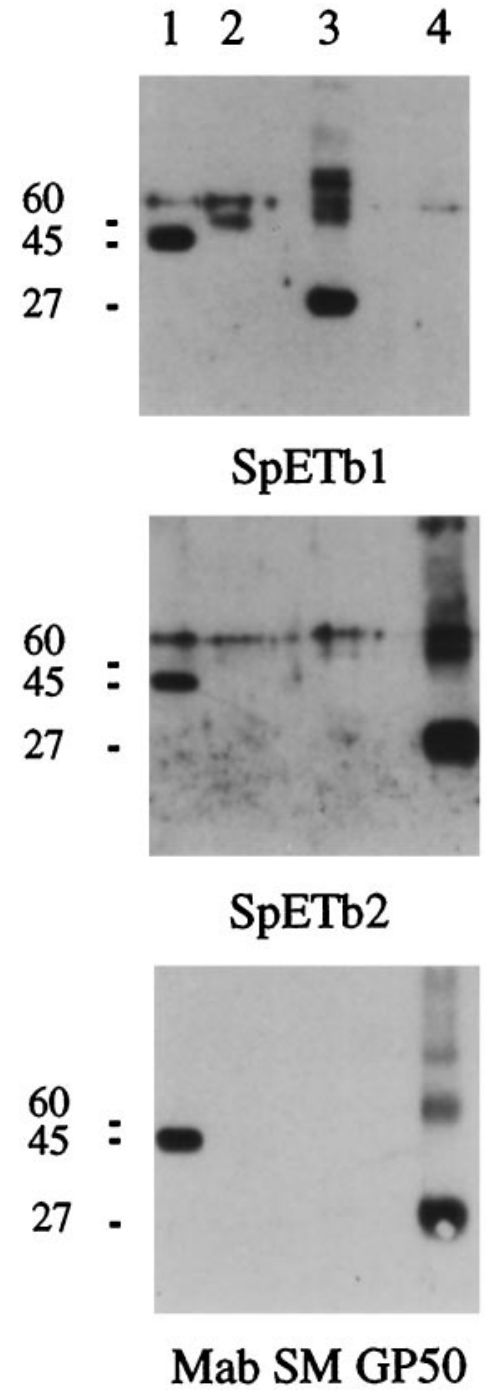

Figure 1. Isoform specificity of anti- $\beta$ subunit antibodies. Antibodies were used to stain samples of rat brain microsomes (lane 1), rat kidney microsomes (lane 2), the truncated human $\beta 1$ protein (lane 3 ), and the truncated human $\beta 2$ protein (lane 4 ). Samples were electrophoresed on $10 \%$ polyacrylamide gels and blotted to nitrocellulose. Bound antibody was detected by chemiluminescence. The apparent molecular weights of the $\beta$ subunits and $\beta$ fragments are indicated on the left. The $\beta 1$ and $\beta 2$ of brain both migrate at $45 \mathrm{kDa}$ (Shyjan et al., 1990), whereas the $\beta 1$ of kidney migrates at $60 \mathrm{kDa}$ (Sweadner and Gilkeson, 1985). The two truncated proteins expressed in E. coli are not glycosylated and migrate at $27 \mathrm{kDa}$; aggregated protein was also present in the preparations, migrating at 60-90 kDa. The slower-migrating, streaky band stained with SpETb1 and SpETb2 in all lanes is an artifact common to rabbit antibodies. The polyclonal antibodies SpETb1 and SpETb2 showed the expected $\beta$ isoform specificities. mAb SM-GP50 reacted exclusively with $\beta 2$.

ular weight of $\beta 1$ in blots of brain and kidney membranes is known to be attributable to differences in glycosylation (Sweadner and Gilkeson, 1985). The polyclonal antibody against $\beta 2, \operatorname{SpETb} 2$, reacted with the $\beta 2$ truncated protein but not at all with the $\beta 1$ truncated protein, and it reacted with a $\beta$ band in rat brain but not rat kidney preparations. This is as expected, because brain expresses both $\beta$ isoforms (Mercer et al., 1986; Pagliusi et al., 1989), whereas kidney expresses only or predominantly $\beta 1$ (MartinVasallo et al., 1989). The mAb SM-GP50 reacted with the $\beta 2$ truncated protein, confirming the report of Gloor et al. (1992). The data here show additionally that it is $\beta 2$-specific, because it did not react with the $\beta 1$ truncated protein or with $\beta 1$ from the rat kidney. Reactivity of all of these antibodies with the truncated proteins expressed in E. coli indicated that the antibodies bind to protein and not carbohydrate epitopes. Because the truncated proteins do not contain the intracellular and transmembrane portions of $\beta$, all of these antibodies also react with epitopes on the extracellular side of the membrane.

The mAb against $\beta 1$, IEC $1 / 48$, did not work on blots, and so could not be tested with the same assay. Its ability to react with $\beta 1$ does not rule out the possibility that it could react with other ATPase gene family $\beta$ subunits as well; it has been noted to stain the apical ciliary epithelium where no known Na,K-ATPase $\alpha$ subunit is found (Coca-Prados et al., 1991), as well as the apical surface of the distal colon epithelium (Marxer et al., 1989) where an H,K-ATPase is found. Consequently, its staining pattern in the cerebellum was compared with that of the polyclonal antibodies against $\beta 1$ (SpETb1) and $\beta 2$ (SpETb2), and with that of the monoclonal anti- $\beta 2$ antibody SM-GP50, to look for any evidence of cross-reactivity. As shown below, its reactivity matched that of the polyclonal $\beta 1$ antibody, and no evidence for cross-reactivity with $\beta 2$ was found. Because the distributions of $\beta$ subunits in cerebellum have substantial overlap, IEC $1 / 48$ was also used on sections of the rat retina, where the $\beta 2$ subunit is expressed at high levels in the photoreceptor inner segments. No cross-reactivity of IEC $1 / 48$ with $\beta 2$ could be detected there (K. J. Sweadner, unpublished observations). Like all of the other antibodies, the $\mathrm{mAb}$ against $\beta 1$ also bound to intact cells, indicating that its epitope is on the extracellular surface.

The mAb originally used to detect $\alpha 3, \mathrm{McBX} 3$ (McGrail and Sweadner, 1989; Urayama et al., 1989; McGrail et al., 1991), has since been determined to recognize a post-translational modification rather than a unique epitope on $\alpha 3$ (Arystarkhova and Sweadner, 1996). The post-translational modification is found on $\alpha 3$ in the brain, but not on $\alpha 3$ in the heart. McBX3 also crossreacts weakly with $\alpha 1$ in the rat and quite strongly with $\alpha 1$ from certain other species. For this reason, a new $\alpha 3$-specific mAb, XVIF9-G10, was used here.

\section{Cerebellar cortex distributions of five $\mathrm{Na}, \mathrm{K}-\mathrm{ATPase}$ isoforms}

Figure 2 summarizes the cellular specificity of isoform distribution that will be documented in the data that follows. In several structures or cell types, it was possible to assign one or more isoforms of $\alpha$ and $\beta$. Where asterisks appear in Figure 2, immunocytochemical evidence for isoforms expression is reported here that was not predicted by previous in situ hybridization studies. Where a pound sign (\#) appears, $\alpha 3$ was unambiguously found in young granule cells in culture, but was not easily detected in granule cell somas in adult animals. Where question marks appear, stain for the $\beta$ subunits could not be distinguished from brighter stain in adjacent cells.

Figure 3 illustrates the different patterns of staining of each of the five $\mathrm{Na}, \mathrm{K}$-ATPase isoforms at relatively low magnification, from the molecular layer (upper left) to the cortical white matter (lower right). The figure demonstrates the complexity of the problem, because no two $\alpha-\beta$ pairs had identical distributions. For the molecular layer, the brightest stain was for $\alpha 2$ and $\beta 2$. For Purkinje cells and basket cell processes, it was $\alpha 3$ and $\beta 1$. For the granular layer, all the isoforms were well represented, but with very different patterns. For the white matter layer, only the $\alpha 3$ isoform showed substantial stain. Each of these layers and isoforms will be considered in more detail below. 


\section{$\begin{array}{llllll}\alpha 1 & \alpha 2 & \alpha 3 & \quad \beta 1 & \beta 2\end{array}$}

\section{Cerebellar cortex:}

\section{Purkinje cells and dendrites}

Basket processes

Granular layer:

Granule cells

Glomeruli

Axons

Astrocytes

Cerebellar white matter:

Axons

Astrocytes

Figure 2. Cell-specific isoform distribution in cerebellum. This diagram summarizes the distribution of identifiable $\mathrm{Na}, \mathrm{K}$-ATPase isoforms in the different layers and cell types of the adult rat cerebellum. A black square indicates high confidence that the isoform is found in the indicated structure, in some cases based not only on immunocytochemistry but also on mRNA localization studies (see Discussion). Asterisks indicate that outlining of Purkinje cell dendrites by antibodies for $\alpha 2$ and $\beta 2$ was found, but it is not supported in the literature by identification of mRNA in the corresponding cell bodies. A pound sign (\#) indicates that stain of granule cells for $\alpha 3$ is light in adult cerebellum. Question marks indicate that $\beta 1$ and $\beta 2$ stain in the granular layer was too bright to allow visualization of either axons or astrocytes.

Figure 4 validates the specificity of the anti- $\beta$ antibodies by showing the similarity of staining when monoclonal and polyclonal antibodies against either $\beta 1$ or $\beta 2$ were compared. Figure $4 A, C$ shows the mAb against $\beta 1$, whereas $4 B$ shows the corresponding polyclonal antibody. Figure $4 D$ shows the polyclonal antibody against $\beta 2$, and Figure $4 E$ shows the corresponding $\mathrm{mAb}$. Figure $4 B, E$ shows a double-label experiment, allowing examination of the subtle differences in staining between $\beta 1$ and $\beta 2$. Figure 5 shows more double-label examples in which staining for $\alpha 1$ was paired with $\beta 1$, and $\alpha 3$ was paired with $\beta 2$. Figure 6 shows four examples of $\alpha 2$ alone, because observed variations in the appearance of its stain could lead to different interpretations. In discussing the details of Na,K-ATPase isoform distribution in the molecular and Purkinje cell layers, Figures 3-6 will be considered as a group below. Higher-magnification pictures of the white matter and granular layers appear in Figures 7 and 8.

\section{The molecular layer}

Although all isoforms were represented in the molecular layer, the distribution of stain showed some subtle differences. The $\alpha 3$ and $\beta 1$ antibodies (Figs. $3 C, 5 C$ for $\alpha 3$; Figs. $3 D, 4 B, C, 5 B$ for $\beta 1$ ) gave a more punctate appearance than the $\alpha 1, \alpha 2$, and $\beta 2$ antibodies (Figs. $3 A, 5 A$ for $\alpha 1$; Fig. 6 for $\alpha 2$; Figs. $3 E, 4 D, E, 5 D$ for $\beta 2$ ), whose stain was very fine-textured and diffuse. The punctae could be synaptic boutons, but their density is too low to be the abundant parallel fiber synapses. It is more likely that they are fine axons, such as the basket cell axons sometimes seen running parallel to the Purkinje cell layer with antibody to $\alpha 3$ (not shown), or perhaps the climbing fibers. Stellate cells also send relatively low-density processes through the molecular layer, ramifying in more distal portions than the basket cell processes. There is also some punctate stain of glial fibers cut in cross section and stained with GFAP, but these are at much lower density (McGrail et al., 1991, their Fig. 1).

\section{The Purkinje cell layer}

Structures stained in the Purkinje cell layer will be described for one isoform at a time. Figures $3 A$ and $5 A$ show the characteristic staining for $\alpha 1$. This isoform was not expressed detectably in Purkinje neurons, which appeared as black holes not even outlined by surrounding glial or neuronal processes. Basket cell processes were also unstained. Faint vertical processes could be seen extending into the molecular layer in Figure $3 A$ (also see McGrail et al., 1991, their Fig. 1). It is not certain what these are, but three possibilities are Bergmann glia, bundles of granule cell axons, or climbing fibers. We occasionally observed some overlap between the vertical structures stained for $\alpha 1$ (seen in Fig. $3 A$ ) and GFAP stain (data not shown); however, the $\alpha 1$ stain coincided with the GFAP stain only close to the Purkinje neurons. The lack of clear association of $\alpha 1$ stain with Purkinje cell dendrites argues against these fibers being climbing fibers, which also should be more solitary and less straight. The vertical structures stained for $\alpha 1$ could be bundles of granule cell axons associated with the Bergmann glial cell as a result of developmental events.

The presence of $\alpha 2$ in Purkinje neurons and basket cell processes was more ambiguous. Four examples are shown in Figure 6 to illustrate the variety of staining patterns seen. In some cases, the Purkinje neurons appeared to be ring-stained (Fig. 6C,D), and clear outlining of the Purkinje cell dendrites was seen occasionally (Fig. 6A,D, arrows). In other cases, the Purkinje neurons themselves seemed as unstained for $\alpha 2$ as they were for $\alpha 1$ (Fig. 6B). In most cases, the absence of stain in the basket cell processes was obvious, but occasionally images were seen that resembled basket cell staining (Fig. 6A, asterisk); however, this stain was quite different from that seen with antibodies against $\alpha 3$ and $\beta 1$. The presence of both circular and wispy profiles that seemed to be coextensive with irregular stained processes deeper in the granular layer makes it likely that the peribasket staining was actually in astrocytes. What is not entirely clear is whether a subset of Purkinje neurons actually expressed $\alpha 2$, as suggested by stain of Purkinje dendrites (Fig. 6A,D).

The new mAb against $\alpha 3$ stained the same structures reported previously using the $\mathrm{McBX} 3 \mathrm{mAb}$ and a polyclonal antibody (McGrail et al., 1991), and no new structures were stained. $\alpha 3$ staining was seen in the Purkinje cell bodies and prominently in the basket cell processes at their base (Figs. 3C, 5C). Basket cell axons stained for $\alpha 3$ were sometimes seen passing through the molecular layer parallel to the Purkinje cell layer, and basket cell somas were also occasionally seen ring-stained for $\alpha 3$ (not shown).

With both antibodies to $\beta 1$ (Figs. $3 D, 4 A-C, 5 B$ ), the Purkinje neurons were outlined and the basket cell processes were clearly stained, but outlining of Purkinje cell dendrites was more visible in Figure $4 A$, whereas the fine fibers of the basket were more visible in Figure $4 C$ (also at higher magnification). Figure $4 B$ shows that the polyclonal antibody against $\beta 1$ stained with substantially the same pattern as the mAb, albeit with higher diffuse background. The similarity suggests that the mAb against $\beta 1$ is indeed specific for $\beta 1$ in this tissue, particularly when contrasted with the stain for $\beta 2$. 


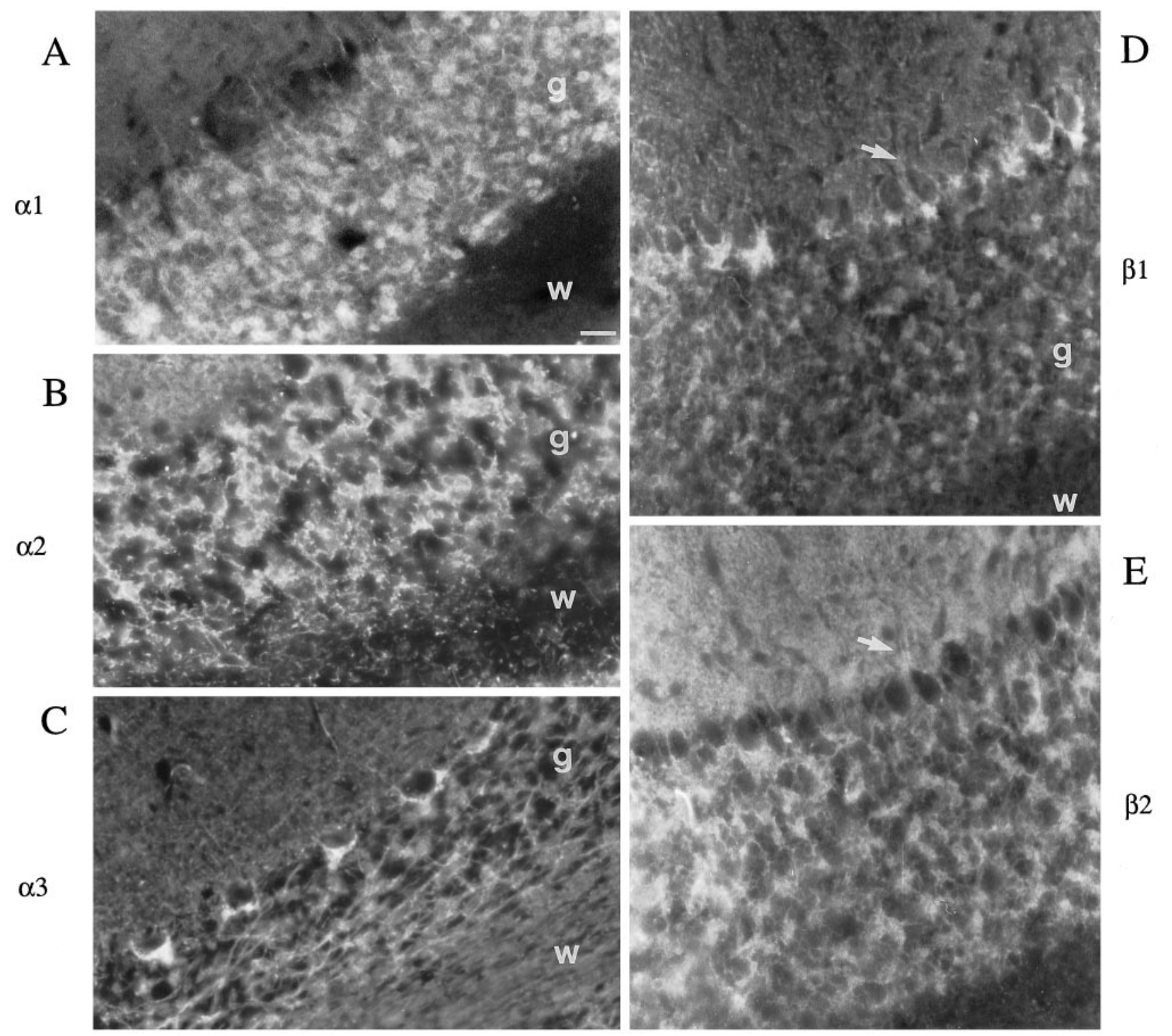

Figure 3. $\alpha$ and $\beta$ isoform distribution in cerebellar layers. Cryosections of adult rat cerebellum, previously fixed with methanol, were stained with $(A)$ $\alpha 1$-specific mAb, $(B) \alpha 2$-specific mAb, $(C) \alpha 3$-specific mAb, $(D) \beta 1$-specific polyclonal antibody, and $(E) \beta 2$-specific mAb. $G$, Granular layer, $w$, white matter. Note that $D$ and $E$ are the same section, double-labeled with anti-rabbit and -mouse secondary antibodies. The white arrow in $D$ and in $E$ points to Purkinje cell dendrites that are outlined by stain for $\beta 2$ but not for $\beta 1$. Scale bar (shown in $A$ ): $30 \mu \mathrm{m}$.

$\beta 2$ distribution is seen in Figures $3 E, 4 D, E$, and $5 D$. Figure $4 D, E$ compares polyclonal and mAbs against $\beta 2$. Purkinje cells were again ring-stained, but no stain of the basket cell processes was visible. The differences between the distributions of $\beta 1$ and $\beta 2$ are best appreciated from two double-label experiments: Figures $3 D, E$ and $4 B, E$, where polyclonal $\beta 1$ and monoclonal $\beta 2$ antibodies stained the same sections, double-labeled with FITC- and TRITC-conjugated anti-rabbit and anti-mouse secondary antibodies. The exclusive labeling of the basket cell processes for $\beta 1$ and not $\beta 2$ can be seen. In Figure $3 D, E$, Purkinje cell dendrites were outlined by stain for $\beta 2$ but not as clearly by stain for $\beta 1$.

Figure 5 shows two other pairs of double-labeled cerebellar sections, contrasting the distributions of Na,K-ATPase $\alpha$ and $\beta$ isoforms. When $\mathrm{mAb}$ against $\alpha 1$ and polyclonal antibody against $\beta 1$ were compared (Fig. $5 A, B$ ), there were clear differences in the outlining of Purkinje cells and staining of baskets. It is also notable that the antibody against $\alpha 1$ stained the pia and adjacent interstitial substance, whereas the antibody against $\beta 1$ did not. When the mAb against $\alpha 3$ and polyclonal antibody against $\beta 2$ were compared (Fig. 5C,D), both antibodies outlined the Purkinje neurons, but only the antibody against $\alpha 3$ stained the baskets.

\section{Glia in the cerebellar cellular layers}

It has already been shown that GFAP stain of cerebellar sections does not colocalize clearly with any of the Na,K-ATPase $\alpha$ isoforms (McGrail et al., 1991), and the same is true of the $\beta$ isoforms. The principal problem is that GFAP, as a cytoskeletal marker, does not faithfully show the entirety of the astrocyte or Bergmann cell and does not mark the position of membrane processes surrounding neurons. It is notable that no $\mathrm{Na}, \mathrm{K}$ ATPase isoform-specific antibody consistently stained Bergmann glia at a level that stood out against the more diffuse stain of other elements. It would seem that quantitatively, the level of $\mathrm{Na}, \mathrm{K}$ ATPase in the Bergmann glia and other structures is low com- 


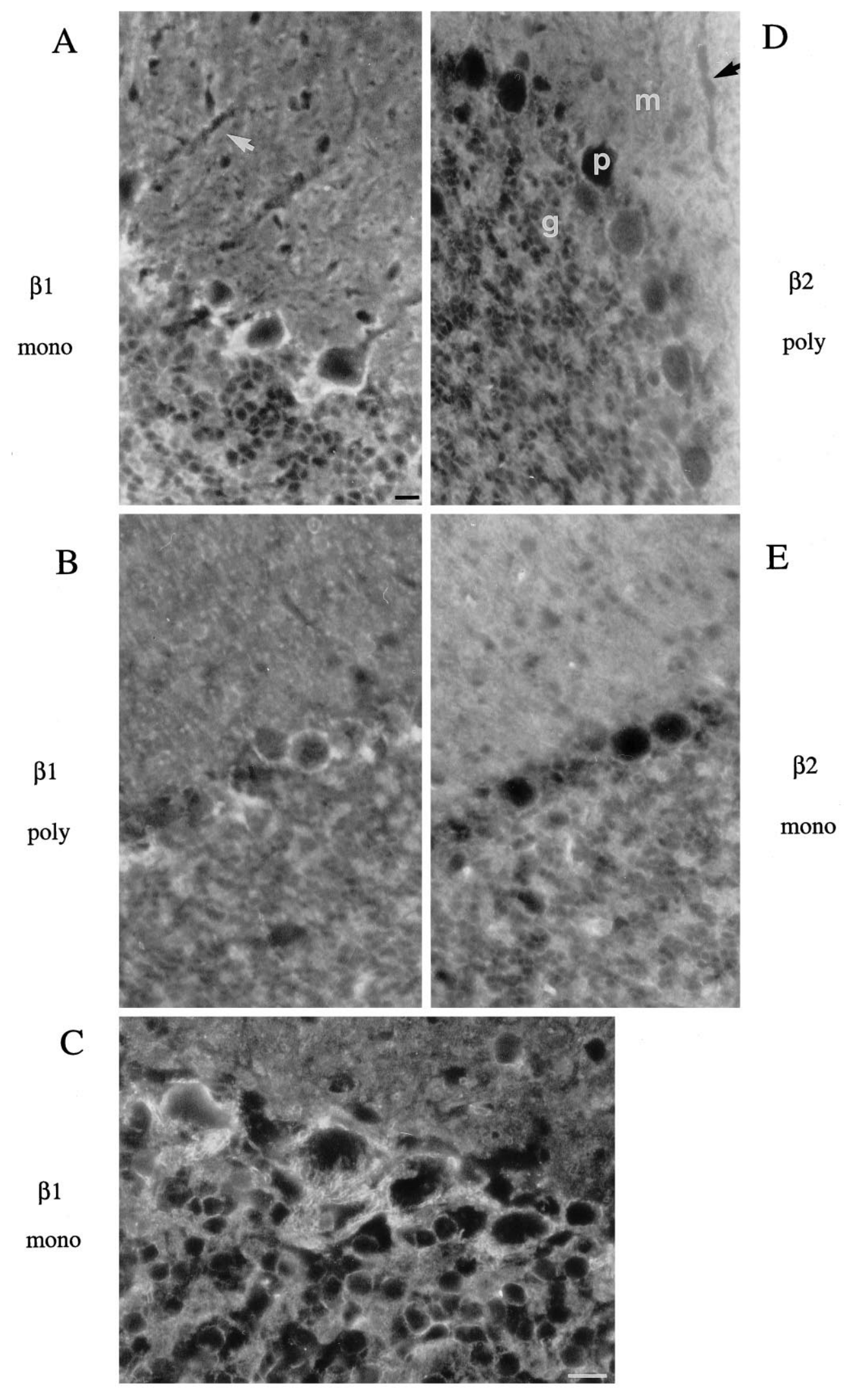

Figure 4. $\quad \beta 1$ and $\beta 2$ isoform distribution in the Purkinje cell layer. Sections of cerebellum were stained with mono- and polyclonal antibodies against $\beta 1$ and $\beta 2$. $A$, $C$, $\beta 1$-specific $\mathrm{mAb} ; B, \beta 1$-specific polyclonal antibody; $D, \beta 2$-specific polyclonal antibody; $E, \beta 2$-specific mAb. In each picture, the molecular layer $(m)$ is at the top and the granular layer $(g)$ is at the bottom. $P$, Purkinje cells. The arrow in $A$ marks a Purkinje cell dendrite; the structure marked by the arrow in $D$ is less certain; it could be a blood vessel. $C$, 1.6-fold higher magnification than $A, B, D, E$. Scale bars (shown in $A$ and $C$ ): $20 \mu \mathrm{m}$. 


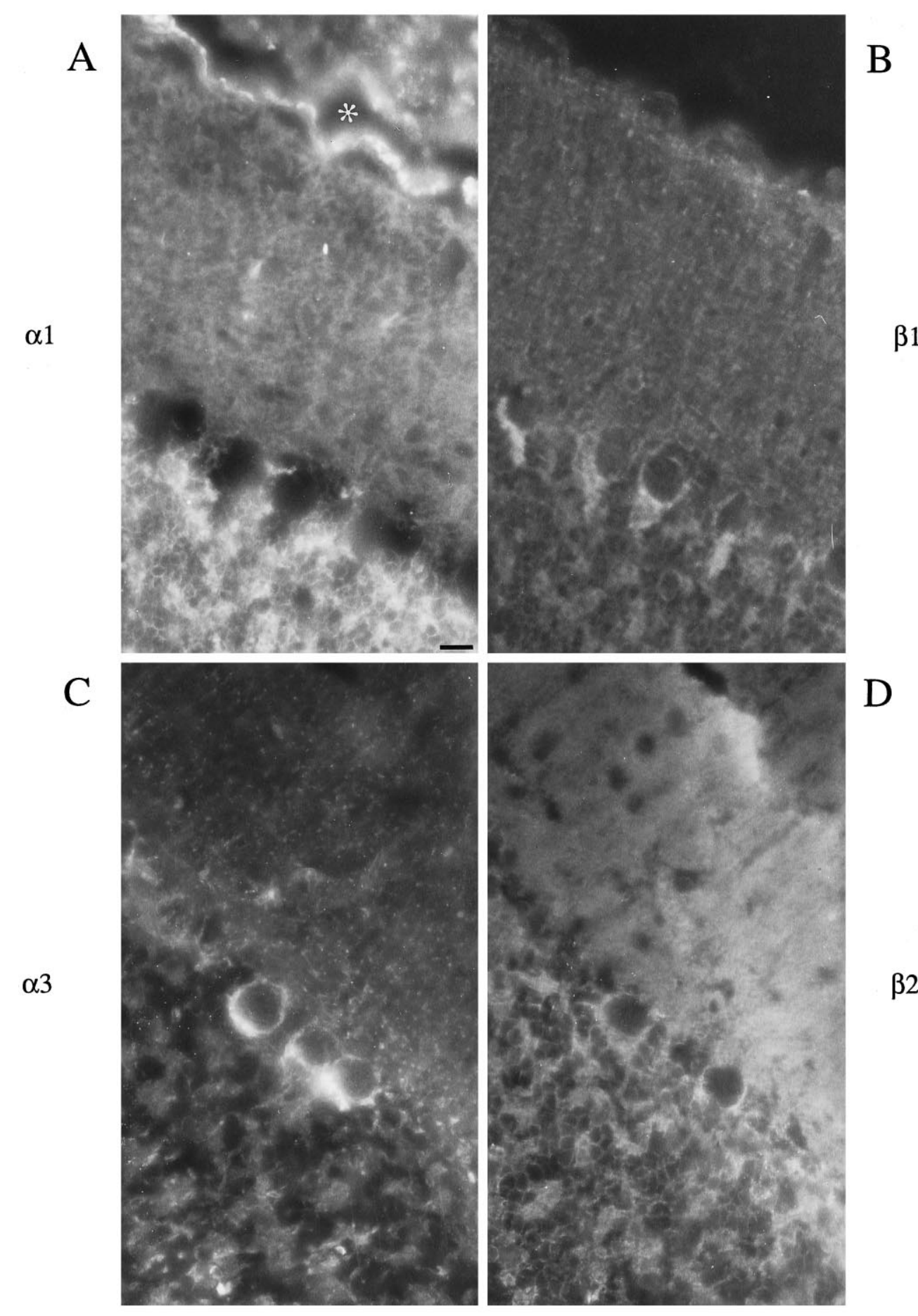

Figure 5. Double-label stain for $\alpha 1$ and $\beta 1$, and $\alpha 3$ and $\beta 2$. Sections were doublelabeled with mouse and rabbit antibodies. $A, \alpha 1$-specific mAb; $B, \beta 1$-specific polyclonal antibody; $C, \alpha 3$-specific mAb; $D$, $\beta 2$-specific polyclonal antibody. The asterisk in $A$ marks a space between pia and overlying layers. In each figure, the molecular layer is in the top right zone, and the granular layer in the bottom left zone, with the Purkinje layer in between. Scale bar (shown in $A$ ): $20 \mu \mathrm{m}$.

pared with that in the granule cell axons that pack the molecular layer.

\section{White matter}

Figure 3 illustrates the staining of white matter within the cerebellar cortex with the various anti-Na,K-ATPase isoform antibodies, comparing the intensity of stain for each of the isoforms with that for the cellular layers. There was remarkably little stain for $\alpha 1$ in white matter (Fig. 3A). This is in contrast with certain other CNS white matter tracts, which sometimes have prominent stain for $\alpha 1$ in axons (McGrail et al., 1991). $\alpha 3$ was the only isoform whose staining of white matter was as high or higher than that of the adjacent granular layer (Fig. $3 C$ ). All of the other antibodies $(\alpha 2, \beta 1$, and $\beta 2)$ showed low levels of stain in white matter (Fig. $3 B, D, E$ ).

Figure 7 shows the transition between the granular layer and the white matter at higher magnification, omitting $\alpha 1$ because there was negligible white matter stain to show. Staining for both $\alpha 2$ (Fig. 7A) and $\beta 2$ (Fig. 7D) had the pattern characteristic of fibrous astrocytes, as reported previously (McGrail et al., 1991; Lecuona et al., 1996). When stained for $\alpha 3$, axons coursing through the granular layer were seen to be concentrated in the white matter, and in $7 B$ they were seen as tubular or circular 


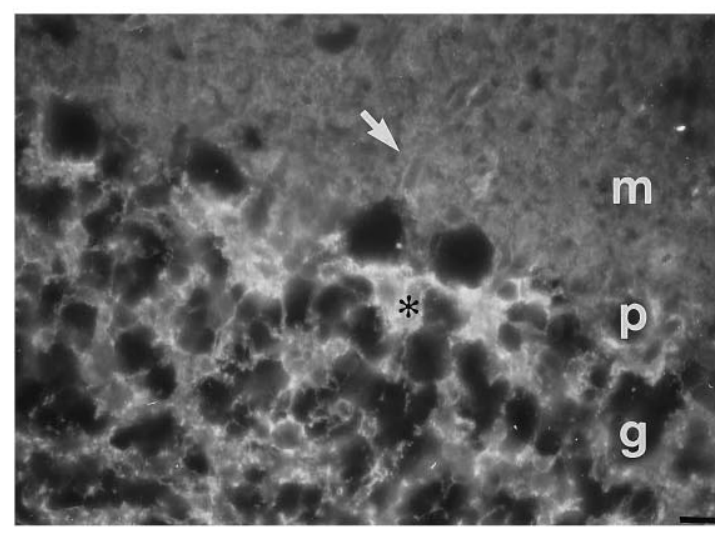

A

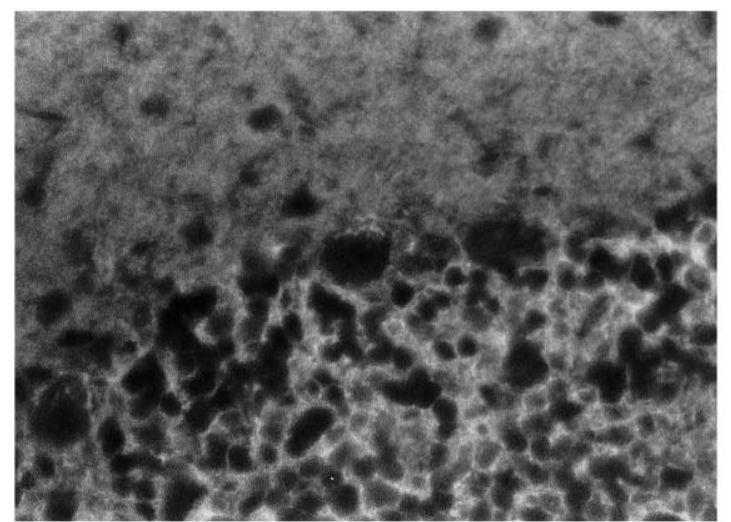

$\alpha 2$

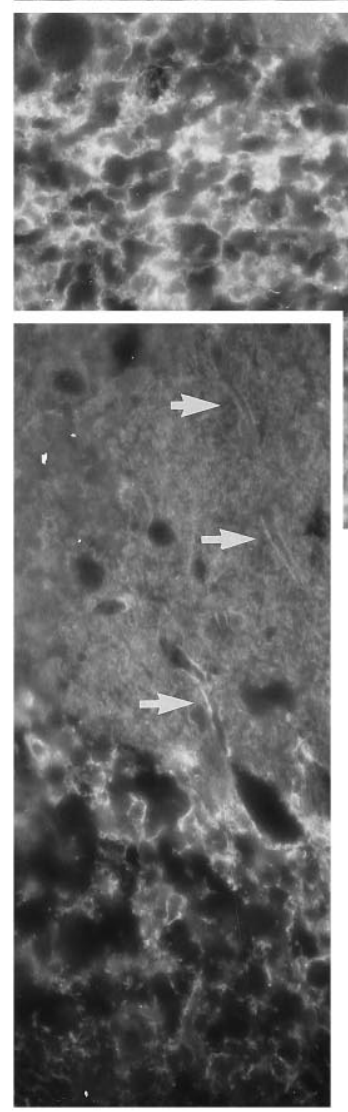

Figure 6. Variations in appearance of $\alpha 2$ stain. Sections were stained with $\alpha 2$-specific $\mathrm{mAb}$, and four examples were chosen to illustrate the range of patterns seen. Each picture shows portions of the molecular layer $(m)$, Purkinje cell layer $(p)$, and granular layer $(g)$, with the granular layer at the bottom. White arrows in $A$ and $D$ show Purkinje cell dendrites profiles. Staining for $\beta 1$ was more ambiguous (Fig. $7 C$ ). It appeared to be in neuronal processes, but the staining was clearly different from that for $\alpha 3$. Because afferent and efferent fibers run in different paths in the cerebellar white matter, one possibility is that both sets of fibers stained for $\alpha 3$ (small diameter ones running more or less parallel to the plane of the photograph; larger diameter ones cut in cross section and appearing as circular profiles), whereas only one set of fibers stained for $\beta 1$ (the smaller diameter ones). It is also possible that other cells, perhaps oligodendrocytes, were stained for $\beta 1$, contributing to a more diffuse appearance.

\section{Granule cells and the granular layer}

Close examination of the granular layer reveals a considerable amount of detail about Na,K-ATPase isoform distribution (Fig. 8). The three $\alpha$ isoforms have distinctly different patterns. Antibodies to $\alpha 1$ (Fig. $8 A$ ) ring-stained the granule cells and brightly stained something in the glomeruli, which are expanded mossy fiber axon terminals complexed with granule cell dendrites and Golgi neuron axon terminals. Antibodies to $\alpha 2$ (Fig. $8 B$ ) did not convincingly ring-stain the granule cells, but instead stained diffuse processes that insert between and around them, and which are almost certainly the processes of astrocytes. In Figure 1 of McGrail et al. (1991), GFAP stain was seen in a similar pattern; in Figure 10 (below) the antibody against $\alpha 2$ was seen to brightly stain astrocytes in cerebellar cell cultures. $\alpha 2$ antibody did not stain glomeruli as a structure distinguishable from the granule cells, and it is likely that astrocytic processes in glomeruli do not have any particular concentration of $\alpha 2$ Na,K-ATPase. Antibodies to $\alpha 3$ (Fig. $8 C$ ) stained straighter, often visibly tubular structures that seem to be axons; these were never stained for $\alpha 1$ or $\alpha 2$. It was not possible to determine whether the axons were descending Purkinje cell axons or ascending mossy or climbing fibers. Glomeruli, however, were stained diffusely for $\alpha 3$. In rare cases, some ring-staining of granule cells has been seen with the $\alpha 3$ antibody. Figure $8 D$ shows an example in which tearing of the section separated some granule cells from adjacent Purkinje neurons and baskets, and the granule cells were visibly, if lightly, stained (arrow).

In contrast to the $\alpha$ isoforms, the two $\beta$ isoforms showed staining patterns that were very similar to one another in the granular layer (Fig. 8E,F). Both of them ring-stained granule cells clearly, and both stained glomeruli (asterisks). Neither of them stained axons passing through the granular layer, and neither of them stained astrocytes unambiguously. In both cases, light stain of these structures simply may not be visible in the background of the granule cells and glomeruli. In fact, the granular layer staining for $\alpha 1$ and $\beta 2$ was difficult to distinguish; staining of the glomeruli by $\beta 1$ was somewhat lighter, but still visible.

In double-label experiments, a correspondence could be seen in the stain of glomeruli between $\beta 1$ and $\beta 2$ (Figs. 3D,E, 4B,E), between $\alpha 1$ and $\beta 1$ (Fig. 5A,B), and between $\alpha 3$ and $\beta 2$ (Fig. $5 C, D)$.

$\leftarrow$

outlined by antibodies for $\alpha 2$. The black asterisk in $A$ marks a concentration of stain for $\alpha 2$ at the base of the Purkinje cell that in some ways resembles basket cell processes, but these structures are stained much more clearly for $\alpha 3$ in Figures $3 C$ and $5 C$. In Fig. $6 C$, the white arrow marks stained circular profiles close to the Purkinje cell bodies that may be glial processes. These are too small (2-3 $\mu$ m diameter) to be granule cells (5-8 $\mu \mathrm{m}$ diameter). Scale bar (shown in $A$ ): $20 \mu \mathrm{m}$. 

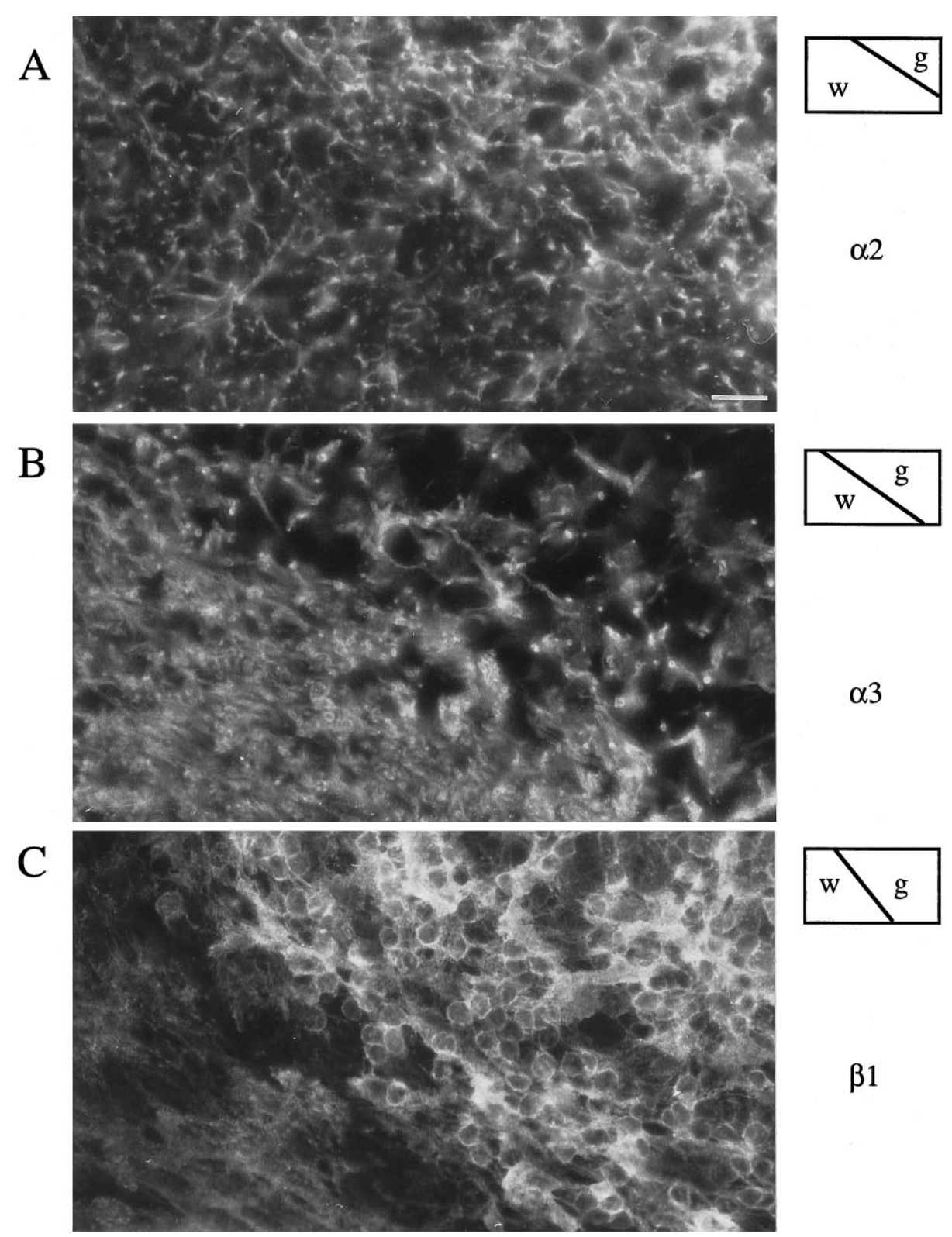

Figure 7. Isoforms in axons and glia in cerebellar white matter. The box to the right of each figure shows the approximate location of the boundary between the granular layer and the white matter in each picture. $A, \alpha 2$-specific mAb; $B, \alpha 3$-specific $\mathrm{mAb} ; C, \beta 1$-specific mAb; $D, \beta 2$-specific polyclonal antibody. $\alpha 2$ and $\beta 2$ appear to stain white matter astrocytes. The very different appearance of stain for $\alpha 3$ and $\beta 1$ is striking; it should be noted that the examples shown were from the same set of sections and were stained at the same time. Scale bar (shown in $A$ ): $20 \mu \mathrm{m}$.

\section{$\mathrm{D}$}

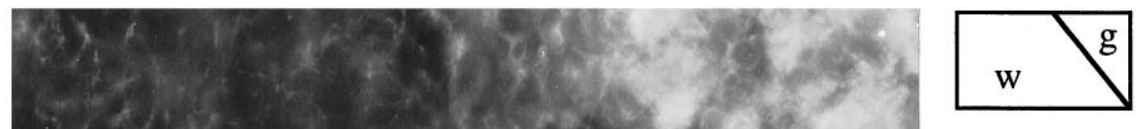

\section{Granule cells and astrocytes in coculture}

Figure 9 shows Western blots of Na,K-ATPase subunits expressed in cerebellar granule cell cultures. Rat brain cerebral microsomes were used as a positive control for the antibodies. All of the $\mathrm{Na}, \mathrm{K}-\mathrm{ATPase}$ isoforms were detected in the cultures, and their proportions were similar to those found in the microsomes.
Figures 10 and 11 show the expression of each isoform in neurons and glia, along with stain for the glial marker GFAP and phase-contrast images. Granule cells by far outnumber other neurons in the cerebellum, and we did not observe any survival of large neurons such as Purkinje cells. When there were a large number of glial cells, the granule cells adhered to them and 


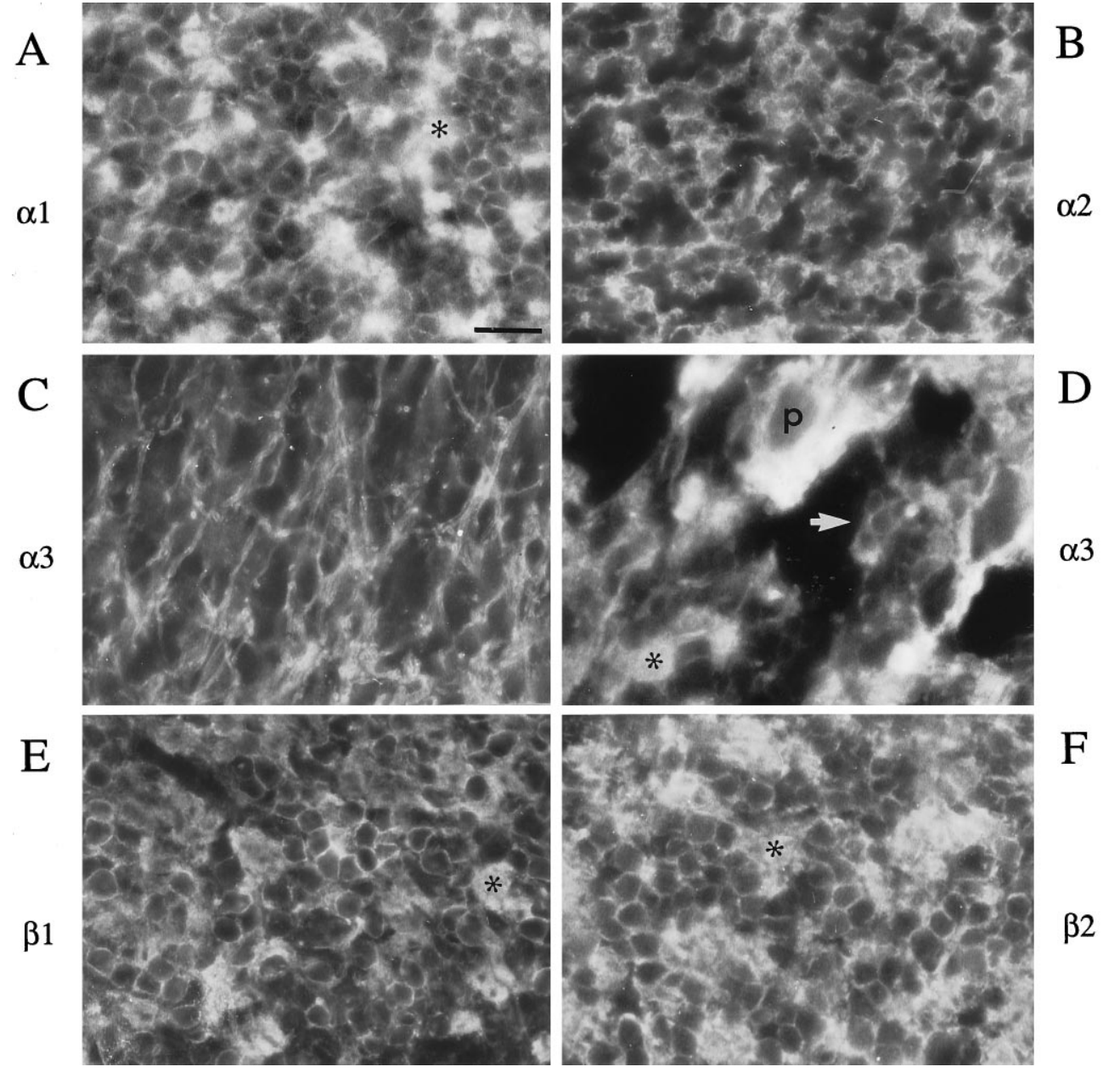

Figure 8. Isoforms in the granular layer. Sections were stained with $(A) \alpha 1$ specific $\mathrm{mAb},(B) \alpha 2$-specific $\mathrm{mAb},(C$, D) $\alpha 3$-specific $\mathrm{mAb},(E) \quad \beta 1$-specific $\mathrm{mAb},(F) \beta 2$-specific polyclonal antibody. Asterisks in $A, D, E$, and $F$ indicate typical glomeruli. In $D$, the $P$ marks a Purkinje neuron that also has brightly stained basket processes adhering to it. The arrow lies on a tear in the section and points to a group of presumptive granule cells that are lightly ring-stained for $\alpha 3$. Scale bar (shown in $A$ ): $20 \mu \mathrm{m}$.

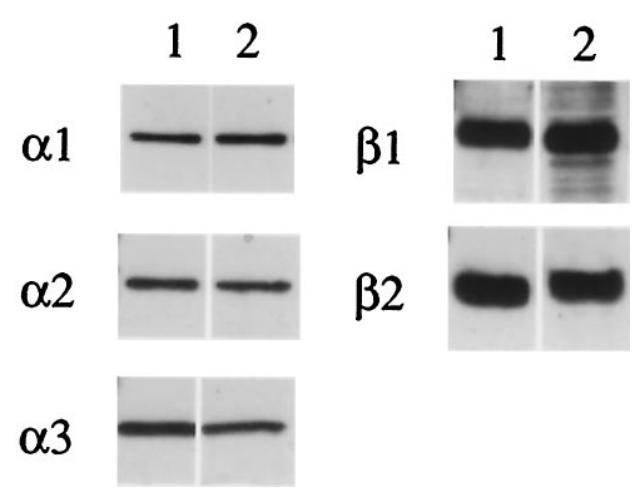

Figure 9. Isoform composition of cerebellar granule cell cultures. Samples of membranes from rat forebrain (lane 1) and rat granule cell cultures (lane 2) were electrophoresed on a $10 \%$ polyacrylamide gel and blotted to nitrocellulose, and the blots were stained with isoform-specific antibodies. $\alpha 1, \alpha 2, \alpha 3$, and $\beta 2$ staining used mAbs; $\beta 1$ was stained with $757 \beta$, an antiserum against a peptide from the $\mathrm{N}$ terminus of $\beta 1$ that works well on blots (Sun and Ball, 1992). All of the isoforms found in the brain were also found in the 7-d-old cultures.

remained spread out on the coverslip. When there were few glia, the neuronal cell bodies gathered into clumps, and bundles of processes extended between the clumps.

The antibody to $\alpha 1$ ring-stained granule cell neurons in culture as it did in adult animals in cerebellar sections. Neuronal processes were clearly stained as well (Fig. 10A). Astrocytes in the same cultures, identified by GFAP stain (Fig. 10B), were usually stained much more lightly for $\alpha 1$ than the neurons, although occasionally brightly stained GFAP-positive cells were seen. Unlike $\alpha 1, \alpha 2$ stain was seen exclusively in astrocytes (Fig. 10D). It was characteristic that the stain uniformly labeled the surface of the cells and generally showed more detail than the GFAP stain (Fig. 10E), because bundles of glial filaments tend to be concentrated in the cytoplasm. This corresponded to the staining pattern seen in tissue sections, where the antibody against $\alpha 2$ stained processes between neurons more completely than GFAP (Figs. 6, $7 A, 8 B)$. The antibody against $\alpha 2$ was a particularly good marker for astrocytes in these cultures. On the basis of the scanty stain of cells in the granular layer for $\alpha 3$, we were surprised to see abundant $\alpha 3$ expressed in the blots of cultures in Figure 9. This $\alpha 3$ proved to be exclusively in neurons, and more interestingly, ringstaining of the granule cell bodies was seen, as well as of the neuronal processes (Fig. 10G). The absence of clear $\alpha 3$ cell body staining in sections (above) could be attributable to age-related differences or to a loss of polarity in culture.

The antibodies against each $\beta$ subunit also stained the granule neurons, as shown in Figure 11. mAb to $\beta 1$ ring-stained the granule neurons brightly, as well as staining processes (Fig. 11 $A$ ). A longer exposure of the same field showed that GFAP-positive astrocytes also were stained very faintly (Fig. $11 B$ ); GFAP is shown in $11 C$. Polyclonal antibody to $\beta 2$ stained granule neurons, neuronal processes (devoid of the GFAP marker), and GFAP-positive astrocytes (Fig. $11 E$ ). Preliminary studies with an antibody against $\beta 3$ showed 

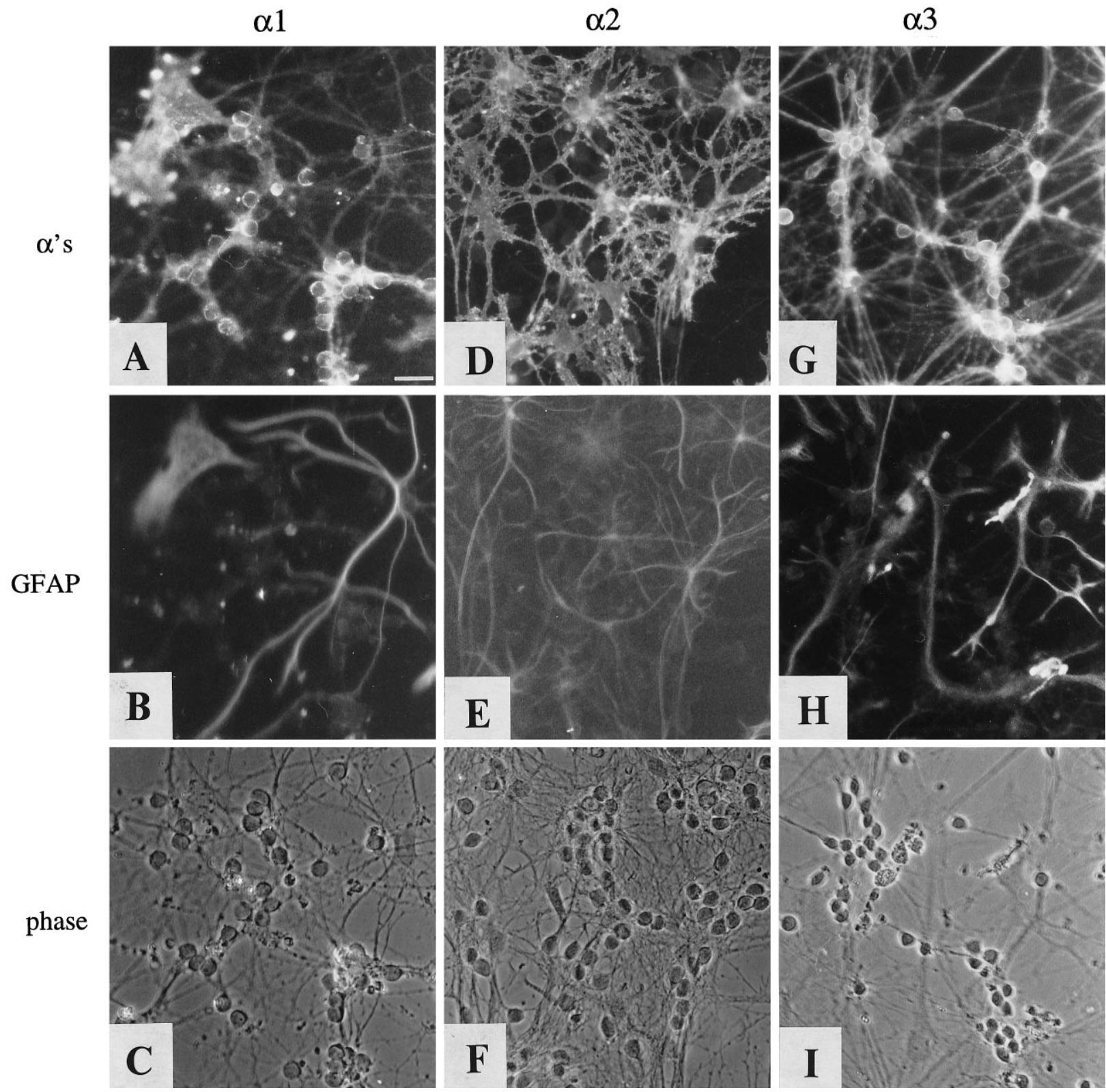

Figure 10. $\alpha$ isoforms in cerebellar granule cell cultures. Seven-day-old cultures were fixed and double-labeled with anti-Na,K-ATPase antibodies and antibody to GFAP. Phase-contrast images show the granule neurons and their bundles of processes. $A, D, G, \alpha 1, \alpha 2$, and $\alpha 3$ were stained with mAbs; $B, E, H$, GFAP was stained with polyclonal antibody. $C, F, I$, Phase-contrast image of the same field. $\alpha 1$ was seen in both neurons and glia, $\alpha 2$ only in glia, and $\alpha 3$ only in neurons in these cultures. Scale bar (shown in $A$ ): $20 \mu \mathrm{m}$.

light staining qualitatively similar to that for $\beta 1$ and $\beta 2$ : expression in both neurons and glia (data not shown).

\section{DISCUSSION}

\section{Isoform distribution in the cerebellum}

Comparing the cellular distributions of the Na,K-ATPase isoforms makes it possible to document the diversity of $\alpha-\beta$ pairing and to clarify some controversial issues. The three $\alpha$ isoforms have distinctive distributions in the cerebellum (Brines et al., 1991; McGrail et al., 1991; Watts et al., 1991). Early reports on location of $\beta 1$ and $\beta 2$ as unidentified $\mathrm{mAb}$ epitopes seemed to conflict (Hirn et al., 1982; Antonicek et al., 1987; Beesley et al., 1987). Magyar et al. (1994) stained P17 mouse cerebellum with antibodies that recognized $\beta 1$ and $\beta 2$, but the patterns were so similar we postulated that the antibodies could have been cross-reacting. Here, after eliminating cross-reactivity and using two different antibodies for each isoform, we found $\beta 1$ and $\beta 2$ distributions in the granular layer and molecular layer that were similar except in the Purkinje neurons and adjacent basket cell processes, which were stained more clearly for $\beta 1$. Stain for $\beta 2$ in these structures or in unidentified processes under the Purkinje cells has been reported as well (Beesley et al., 1987, 1990; Lecuona et al., 1996). Coupled with the observation that granule neurons display $\beta 2$ in addition to $\beta 1$, we can conclude that coexpression of the two $\beta$ isoforms predominates in cerebellar cortex. In contrast, the two $\beta$ isoforms have different distributions in cerebellar white matter and also are partially segregated in the rat retina (R. K. Wetzel and K. J. Sweadner, unpublished observations). 


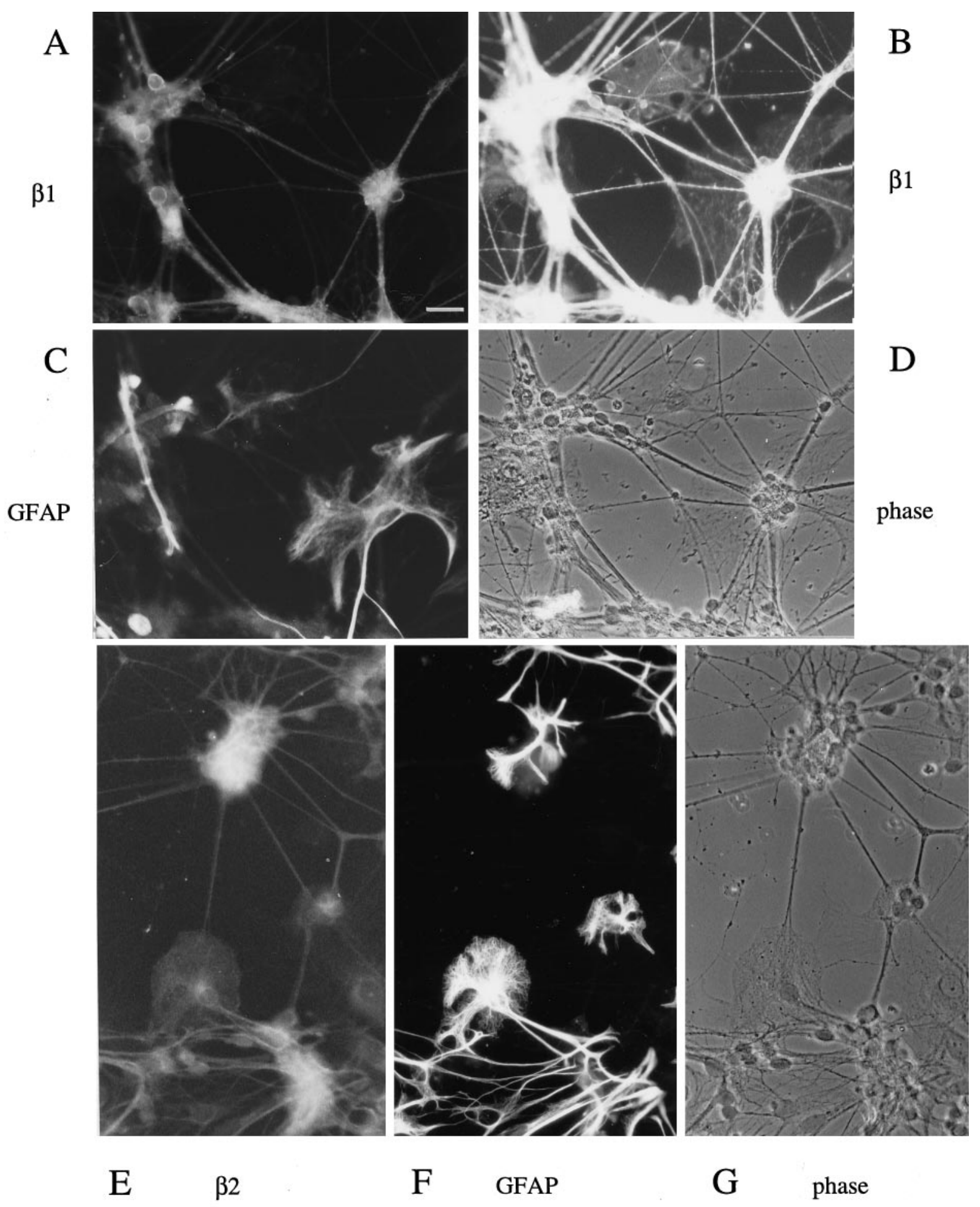

Figure 11. $\quad \beta$ isoforms in cerebellar granule cell cultures. Cultures were prepared and stained as in Figure 10. $A, B, \beta 1$ was stained with mAb; $B$ is a longer exposure of $A$ that illustrates the faint stain of astrocytes. $C$, Double-label staining was with a polyclonal antibody against GFAP. $E, \beta 2$ was stained with polyclonal antibody; $F$, double-label staining was with a mAb against GFAP. $D$, $G$, Phase contrast. Neuronal somas, neuronal processes (free of glial stain), and astrocytes were stained for both $\beta 1$ and $\beta 2$. Scale bar (shown in $A$ ): $20 \mu \mathrm{m}$.

One of the most controversial questions has been the isoform composition of the cerebellar granule neuron. In situ hybridization signal for $\alpha 1$ predominated in the granular layer (Brines et al., 1991; Hieber et al., 1991; Watts et al., 1991), as did immunostain for the protein, which unambiguously ring-stained the gran- ule neurons (McGrail et al., 1991). Signal for $\alpha 2$ mRNA was scattered in the granular layer (Brines et al., 1991; Watts et al., 1991). Immunostain for $\alpha 2$ did not ring-stain the granule neurons but had the wispy and irregular pattern of astrocytes, which do not surround every granule cell (McGrail et al., 1991). Here, $\alpha 2$ - 
specific antibody stained only astrocytes in culture, not granule neurons. Light in situ hybridization signal for $\alpha 3$ was seen over the granular layer (Schneider et al., 1988; Brines et al., 1991; Hieber et al., 1991; Watts et al., 1991), but the cells of origin were unclear, perhaps Golgi cells. Immunostain for $\alpha 3$ was relatively light in adult rat cerebellum (McGrail et al., 1991), and much of it appeared to be in glomeruli or axons passing through, which should not contribute much mRNA signal. Cameron et al. (1994) stained rat and monkey cerebellum for $\alpha 3$ protein; their figures show stain not very different from the $\alpha 3$ stain shown here. Granule neurons isolated from P8 rat cerebellum contained equal signals for $\alpha 1$ and $\alpha 3$ when membrane preparations were tested on immunoblots, however (Cameron et al., 1994), and neither glomeruli nor axons of passage should have contaminated the samples. On the basis of finding $\alpha 3$ in P7 granule cells cultured for 1 week, the conclusion is that $\alpha 3$ is probably present, but at a quantitatively lower level than $\alpha 1$ in the adult.

A similar degree of controversy surrounds the expression of $\beta$ isoforms in cerebellar granule neurons. Antibody BSP-3 (later shown to bind to $\beta 1$ ) stained both granule cells and astrocytes (Hirn et al., 1982). Antibody to AMOG (later shown to be $\beta 2$ ) did not stain external granule layer cells early in mouse cerebellar development (P5), but stained Bergmann glial cells in contact with migrating granule cells (Antonicek et al., 1987). In cells dissociated from P6 mouse cerebellum, astrocytes expressed $\beta 2$ mRNA and protein, whereas neurons did not (Antonicek et al., 1987; Pagliusi et al., 1990). In apparent agreement, $\beta 1$ protein was found in isolated P8 rat granule neurons and $\beta 2$ in cultured cortical (not cerebellar) astrocytes (Cameron et al., 1994). In apparent contradiction, the early work on GP-50 (like AMOG, also later shown to be $\beta 2$ ) indicated that it was specific to granule cells in adult rats (Beesley et al., 1987). $\beta 2$ was found in cultured granule neurons without (Paladino et al., 1990) or with (Antonicek et al., 1987; Gloor et al., 1990) expression in astrocytes. Pagliusi et al. (1990) and Magyar et al. (1994) also showed in situ hybridization signal for $\beta 2$ in the internal granular layer in animals of various ages, including adult; grains seemed to be over granule neurons as well as presumptive Bergmann glia and astrocytes. The results presented here are consistent with the expression of $\beta 1$ and $\beta 2$ in adult and cultured rat granule cells, and with a relatively low level of expression of $\beta 1$ and $\beta 2$ in cultured cerebellar astrocytes. Thus key elements of apparently contradictory previous reports are confirmed or clarified.

The predominant expression of $\alpha 3$ and $\beta 1$ in Purkinje neurons has been reproducible (Hirn et al., 1982; Hieber et al., 1989; Brines et al., 1991; McGrail et al., 1991; Watts et al., 1991; Cameron et al., 1994; Magyar et al., 1994). The Purkinje neuron has a remarkable absence of stain for $\alpha 1$, either in the plasma membrane or in any closely apposed synaptic terminals or glial processes. The "black hole" appearance is unexpected, because $\alpha 1$ is thought to be a housekeeping isoform with upstream regulatory elements that should result in expression at some level in most cells (Kobayashi and Kawakami, 1995). Outlining of Purkinje cell soma and dendrites by antibodies for all of the other isoforms was seen here, including $\beta 2$ and $\alpha 2$. This has been reported before for $\beta 2$ (Beesley et al., 1987; Magyar et al., 1994; Lecuona et al., 1996), and an example of $\alpha 2$ outlining of a presumptive Purkinje cell dendrite can be seen in McGrail et al. (1991). A question is whether the apparent absence of $\alpha 2$ and $\beta 2$ mRNA in this cell is complete or only relative, or whether there is expression in surrounding cell processes that have no detectable $\alpha 1$.

\section{Patterns of isoform expression in excitatory and inhibitory neurons}

The complex geometry and physiology of CNS neurons must be considered when investigating the distribution of Na,K-ATPase isoforms. Purkinje neurons, for example, fire $\mathrm{Na}^{+}$action potentials only in their somas and axons and have predominantly $\mathrm{Ca}^{2+}$ spikes in their dendrites; intracellular $\mathrm{Na}^{+}$transients have correspondingly been detected in the distal portions but not in the dendrites (Lasser-Ross and Ross, 1992). One would expect Na,KATPase to be where $\mathrm{Na}^{+}$movements are pronounced, and one would expect it to be most physiologically important in fine processes where a finite amount of $\mathrm{Na}^{+}$and $\mathrm{K}^{+}$flux would have the largest impact on transmembrane gradients. Selective routing of Na,K-ATPase isoforms to dendrites or axons has been noted for hippocampal pyramidal cells in situ (McGrail et al., 1991) and for reaggregate telencephalic cultures (Brines and Robbins, 1993) but not for cultured hippocampal neurons (Pietrini et al., 1992). In the cerebellum, the finest and most abundant processes are the bifurcating axons of the granule cells in the molecular layer, where antibodies against all five $\mathrm{Na}, \mathrm{K}$-ATPase isoforms stained.

It is plausible that different $\mathrm{Na}, \mathrm{K}$-ATPase isoforms could be important for cells with different modes of neurotransmission. On the presynaptic side, conventional vesicular release mechanisms entail tight control of $\mathrm{Ca}^{2+}$ movements, and $\mathrm{Na}, \mathrm{K}-\mathrm{ATP}$ ase could be important for its role in $\mathrm{Na}^{+} / \mathrm{Ca}^{2+}$ exchange. Release of transmitters like GABA via reversal of $\mathrm{Na}^{+}$-dependent plasma membrane carriers could present a quantitatively larger $\mathrm{Na}^{+}$ transport challenge and require an isoform with different $\mathrm{Na}^{+}$ affinity or other properties. Retinal horizontal cells, for example, may use this transmission mode (Attwell et al., 1993), and they have high levels of both $\alpha 1$ and $\alpha 3$ (McGrail and Sweadner, 1989). On the postsynaptic side, restoration of $\mathrm{Na}^{+}$and $\mathrm{K}^{+}$gradients should be quantitatively more important for excitatory synapses with gated $\mathrm{Na}^{+}$and $\mathrm{Ca}^{2+}$ conductances than for those dominated by changes in chloride conductance. Different levels of neuronal $\mathrm{Na}, \mathrm{K}-\mathrm{ATPase}$ could also be required when the recapture of transmitter via $\mathrm{Na}^{+}$-dependent carriers is or is not provided by adjacent glia.

We can point out examples that suggest that the neurotransmission mode is not a predictor of Na,K-ATPase isoform type. Purkinje neurons and basket cells, for example, are both inhibitory in the cerebellum, and both express predominantly $\alpha 3$ and $\beta 1$. The ganglion cell of the retina, however, also expresses predominantly $\alpha 3$ and $\beta 1$ (R. K. Wetzel and K. J. Sweadner, unpublished observations), and it is excitatory. The granule cell is exclusively excitatory, but $\alpha 1$ is its predominant isoform, and $\alpha 1$ seems to pair with both $\beta 1$ and $\beta 2$. The photoreceptor is also excitatory, but there the isoform combination is $\alpha 3$ with $\beta 2$. In the cerebellum, stellate and Golgi neurons, both inhibitory interneurons, were never seen to be stained for any $\mathrm{Na}, \mathrm{K}$-ATPase isoform above the background of other cells, contrasting with the bright stain of the basket cell termini. The ascending excitatory input to the cerebellum also differed. Climbing fibers were not visible against the background, but mossy fiber terminals, with their tangle of Golgi fiber terminals and granule cell dendrites, were stained for $\alpha 1, \alpha 3, \beta 1$, and $\beta 2$. The mossy fibers use excitatory transmission, whereas the Golgi fibers are inhibitory.

\section{$\mathrm{Na}, \mathrm{K}-\mathrm{ATPase}$ isoform expression in astrocytes}

Astrocytes show variability in the Na,K-ATPase isoforms expressed. In studies of cultures of cortical astrocytes, we have observed differences between rats and mice (Sweadner et al., 
1995). From the mouse, typical flat astrocytes expressed $\alpha 1, \alpha 2$, and $\beta 2$, whereas from the rat, similar cultures expressed only $\alpha 1$ at comparable levels, with a paucity of either known $\beta$ subunit. Rat astrocyte cultures containing more complex astrocyte types expressed $\alpha 2$ as well as $\alpha 1$, but still very little $\beta$. This was mirrored in cerebellar astrocytes here; they expressed $\alpha 2$ at high levels, but compared with the stain of neurons, stain for $\alpha 1, \beta 1, \beta 2$, or $\beta 3$ was light.

Staining of astrocytes in CNS white matter by anti-Na,KATPase holoenzyme antibodies has been shown to colocalize with stain for GFAP (Ariyasu et al., 1985). Similar patterns have been noted for $\alpha 1$ and $\alpha 2$ in optic nerve (McGrail and Sweadner, 1989), for $\alpha 2$ in brainstem (McGrail et al., 1991), and for $\beta 2$ in optic nerve and spinal trigeminal tract (Magyar et al., 1994; Lecuona et al., 1996). In situ hybridization signal is particularly convincing, because only glia have mRNA locally in white matter: both $\alpha 2$ and $\beta 2$ mRNA signal has been reported by some (Pagliusi et al., 1990; Watts et al., 1991; Magyar et al., 1994) but not all investigators (Brines et al., 1991). The present evidence indicates that the fibrous astrocyte typical of white matter expresses $\alpha 2$ and $\beta 2$ in the subcortical white matter of the cerebellum.

\section{Conclusion}

Are there "neuronal" and "glial" isoforms of the Na,K-ATPase? It has been suggested that $\alpha 3 \beta 1$ is the combination typical of neurons and $\alpha 2 \beta 2$ the combination of astrocytes, with $\alpha 1$ found in both classes of cells (Corthesy-Theulaz et al., 1990a,b; Cameron et al., 1994). This is based mostly on observations on the neurons and glia that are easiest to identify: large projection neurons and white matter astrocytes. Although only neurons express $\alpha 3$ in the CNS, it is not always expressed exclusively. Even in tracts of myelinated axons, some have predominantly $\alpha 3$, whereas others have both $\alpha 1$ and $\alpha 3$ (McGrail et al., 1991). It seems that a preponderance of $\alpha 2$ is in astrocytes (Corthesy-Theulaz et al., 1990a,b; McGrail et al., 1991), but $\alpha 2$ can be expressed in neurons as well, as documented for hippocampal pyramidal cells (Filuk et al., 1989; Brines et al., 1991; McGrail et al., 1991; Stahl et al., 1993; Cameron et al., 1994) and other cells (McGrail and Sweadner, 1989; McGrail et al., 1991; Watts et al., 1991). Similarly for the $\beta$ subunits, $\beta 1$ and $\beta 2$ are found in some neurons and some glia. Neurons, consequently, can express any of the Na,K-ATPase isoforms, and glia all but $\alpha 3$.

The cellular architecture of the cerebellum is completely unaffected in $\beta 2$ knockout mice (AMOG 0/0) (Magyar et al., 1994), suggesting that $\beta 1$ or other uncharacterized $\beta$ subunits can perform any critical functions of $\beta 2$. Similarly, grafts of brain tissue from AMOG 0/0 mice have been shown to survive as healthy tissue in host mice for as long as 2 years, without invasion of cells expressing $\beta 2$ (Isenmann et al., 1995). The knockout mice do die at P17-18, however, with enlarged ventricles and spongiform lesions in the brainstem representing vacuolization of astrocytes apposed to blood vessels (Magyar et al., 1994). $\beta 2$ seems to be essential for ion transport in these cells, and the resulting impairment of vital systems leads to death. $\beta 2$ is also expressed in a very specialized neuron, the photoreceptor cell (Schneider and Kraig, 1990; Magyar et al., 1994), which also degenerated in the knockout mouse.

A complex picture of $\mathrm{Na}, \mathrm{K}-\mathrm{ATPase}$ isoform expression in the cerebellum has been presented here. When all of the evidence is considered, it would be most conservative to conclude that $\mathrm{Na}, \mathrm{K}$ ATPase isoform expression is idiosyncratic in the CNS. $\beta 2$ in particular, which has been considered at different times to be unique to either neurons or glia, is clearly shown to be expressed in the cerebellar granule cell, which is the single most abundant neuronal cell type in the brain.

\section{REFERENCES}

Antonicek H, Persohn E, Schachner M (1987) Biochemical and functional characterization of a novel neuron-glia adhesion molecule that is involved in neuronal migration. J Cell Biol 104:1587-1595.

Ariyasu RG, Nichol JA, Ellisman MH (1985) Localization of sodium/ potassium adenosine triphosphatase in multiple cell types of the murine nervous system with antibodies raised against the enzyme from kidney. J Neurosci 5:2581-2596.

Arstarkhova E, Sweadner KJ (1996) Isoform-specific monoclonal antibodies to Na-K-ATPase $\alpha$ subunits: evidence for a tissue-specific posttranslational modification of the $\alpha$ subunit. J Biol Chem 271:23407-23417.

Attwell D, Barbour B, Szatkowski M (1993) Nonvesicular release of neurotransmitter. Neuron 11:401-407.

Beesley PW, Paladino T, Gravel C, Hawkes R, Gurd JW (1986) Is the major synaptic membrane concanavalin A-binding glycoprotein, gp 50, located at the synapse: studies with a monoclonal antibody. Biochem Soc Trans 14:769-771.

Beesley PW, Paladino T, Gravel C, Hawkes RA, Gurd JW (1987) Characterization of gp 50, a major glycoprotein present in rat brain synaptic membranes, with a monoclonal antibody. Brain Res 408:65-78.

Beesley PW, Paladino T, Hill I, Gravel C, Hawkes RB, Gurd JW (1990) Postnatal development of a granule cell-enriched, neurone-specific glycoprotein, gp50, in normal and thyroid-deficient rats. J Neurochem 54:505-512.

Blanco G, Sanchez G, Mercer RW (1995) Comparison of the enzymatic properties of the Na,K-ATPase $\alpha 3 \beta 1$ and $\alpha 3 \beta 2$ isozymes. Biochemistry 34:9897-9903.

Brines ML, Robbins RJ (1993) Cell-type specific expression of Na,KATPase catalytic subunits in cultured neurons and glia: evidence for polarized distribution in neurons. Brain Res 631:1-11.

Brines ML, Gulanski BI, Gilmore-Hebert M, Greene AL, Benz Jr EJ, Robbins RJ (1991) Cytoarchitectural relationships between ouabain binding and mRNA for isoforms of the sodium pump catalytic subunit in rat brain. Brain Res Mol Brain Res 10:139-150.

Cameron R, Klein L, Shyjan AW, Rakic P, Levenson R (1994) Neurons and astroglia express distinct subsets of $\mathrm{Na}, \mathrm{K}-\mathrm{ATPase} \alpha$ and $\beta$ subunits. Mol Brain Res 21:333-343.

Coca-Prados M, Martin-Vasallo P, Hernando-Sobrino N, Ghosh S (1991) Cellular distribution and differential expression of the Na,K-ATPase alpha isoform (alpha 1, alpha 2, alpha 3), beta, and beta 2/AMOG genes in the ocular ciliary epithelium. Soc Gen Physiol Ser 46(part 2):157-163.

Corthesy-Theulaz I, Merillat A-M, Honegger P, Rossier BC (1990a) $\mathrm{Na}(+)-\mathrm{K}(+)$-ATPase gene expression during in vitro development of rat fetal forebrain. Am J Physiol 258:C1062-C1069.

Corthesy-Theulaz I, Rossier B, Honegger P (1990b) Differential expression and developmental regulation of $\mathrm{Na}, \mathrm{K}-\mathrm{ATP}$ ase isoforms in rat fetal telencephalon organotypic cell cultures. Prog Cell Res 1:241-248.

Daly SE, Lane LK, Blostein R (1994) Functional consequences of aminoterminal diversity of the catalytic subunit of the Na,K-ATPase. J Biol Chem 269:23944-23948.

Eakle KA, Kabalin MA, Wang SG, Farley RA (1994) The influence of $\beta$ subunit structure on the stability of $\mathrm{Na} / \mathrm{K}$-ATPase complexes and interaction with $\mathrm{K}^{+}$. J Biol Chem 269:6550-6557.

Felsenfeld DP, Sweadner KJ (1988) Fine specificity mapping and topography of an isozyme-specific epitope of the Na,K-ATPase catalytic subunit. J Biol Chem 263:10932-10942.

Filuk PE, Miller MA, Dorsa DM, Stahl WL (1989) Localization of messenger RNA encoding isoforms of the catalytic subunit of the $\mathrm{Na}, \mathrm{K}$ ATPase in rat brain by in situ hybridization histochemistry. Neurosci Res Commun 5:155-162.

Gloor S, Antonicek H, Sweadner KJ, Pagliusi S, Frank R, Moos M, Schachner M (1990) The adhesion molecule on glia (AMOG) is a homologue of the $\beta$ subunit of the Na,K-ATPase. J Cell Biol 110:165-174.

Gloor S, Nasse K, Essen LO, Appel F (1992) Production and secretion in $\mathrm{CHO}$ cells of the extracellular domain of $\mathrm{AMOG} / \beta 2$, a type-II membrane protein. Gene 120:307-312.

Gonzalez-Martinez LM, Avila J, Marti E, Lecuona E, Martin-Vasallo P (1994) Expression of the $\beta$-subunit isoforms of the Na,K-ATPase in rat embryo tissues, inner ear and choroid plexus. Biol Cell 81:215-222. 
Hieber V, Siegel GJ, Desmond ST, Liu JL-H, Ernst SA (1989) Na,KATPase: comparison of the cellular localization of alpha-subunit mRNA and polypeptide in mouse cerebellum, retina, and kidney. J Neurosci Res 23:9-20.

Hieber V, Siegel GJ, Fink DJ, Beaty MW, Mata M (1991) Differential distribution of $(\mathrm{Na}, \mathrm{K})$-ATPase alpha isoforms in the central nervous system. Cell Mol Neurobiol 11:253-262.

Hirn M, Pierres M, Deagostini-Bazin H, Hirsch MR, Goridis C, Ghandour MS, Langley OK, Gombos G (1982) A new brain cell surface glycoprotein identified by a monoclonal antibody. Neuroscience 7:239-250.

Isenmann S, Molthagen M, Brandner S, Bartsch U, Kühne G, Magyar JP, Sure U, Schachner M, Aguzzi A (1995) The AMOG/ $\beta 2$ subunit of the $\mathrm{Na}, \mathrm{K}-\mathrm{ATPase}$ is not necessary for long-term survival of telencephalic grafts. Glia 15:377-388.

Jaisser F, Canessa CM, Horisberger JD, Rossier BC (1992) Primary sequence and functional expression of a novel ouabain-resistant $\mathrm{Na}, \mathrm{K}$ ATPase: the beta subunit modulates potassium activation of the $\mathrm{Na}, \mathrm{K}$ pump. J Biol Chem 267:16895-16903.

Jewell EA, Lingrel JB (1991) Comparison of the substrate dependence properties of the rat $\mathrm{Na}, \mathrm{K}-\mathrm{ATPase}$ alpha 1 , alpha 2 , and alpha 3 isoforms expressed in HeLa cells. J Biol Chem 266:16925-16930.

Jørgensen PL (1974) Isolation of (Na + K) ATPase. Methods Enzymol 32:277-290.

Kobayashi M, Kawakami K (1995) ATF-1CREB heterodimer is involved in constitutive expression of the housekeeping Na,K-ATPase $\alpha 1$ subunit gene. Nucleic Acids Res 23:2848-2855.

Lasser-Ross N, Ross WN (1992) Imaging voltage and synaptically activated sodium transients in cerebellar Purkinje cells. Proc R Soc Lond [Biol] 247:35-39.

Lecuona E, Luquin S, Avila J, Garcia-Segura LM, Martin-Vasallo P (1996) Expression of the $\beta 1$ and $\beta 2$ (AMOG) subunits of the Na,KATPase in neural tissues: cellular and developmental distribution patterns. Brain Res Bull 40:167-174.

Magyar JP, Bartsch U, Wang ZQ, Howells N, Aguzzi A, Wagner EF, Schachner M (1994) Degeneration of neural cells in the central nervous system of mice deficient in the gene for the adhesion molecule on glia, the $\beta 2$ subunit of murine Na,K-ATPase. J Cell Biol 127:835-845.

Malik N, Canfield VA, Beckers MC, Gros P, Levenson R (1996) Identification of the mammalian Na,K-ATPase $\beta 3$ subunit. J Biol Chem 271:22754-22758.

Martin-Vasallo P, Dackowski W, Emanuel JR, Levenson R (1989) Identification of a putative isoform of the Na,K-ATPase beta subunit: primary structure and tissue-specific expression. J Biol Chem 264:4613-4618.

Marxer A, Stieger B, Quaroni A, Kashgarian M, Hauri HP (1989) (Na + K)-ATPase and plasma membrane polarity of intestinal epithelial cells: presence of a brush border antigen in the distal large intestine that is immunologically related to beta subunit. J Cell Biol 109:1057-1069.

McGrail KM, Sweadner KJ (1989) Complex expression patterns for $\mathrm{Na}, \mathrm{K}-\mathrm{ATP}$ ase isoforms in retina and optic nerve. Eur $\mathbf{J}$ Neurosci 2:170-176.

McGrail KM, Phillips JM, Sweadner KJ (1991) Immunofluorescent localization of three Na,K-ATPase isozymes in the rat CNS: both neurons and glia can express more than one Na,K-ATPase. J Neurosci 11:381-391.

Mercer RW, Schneider JW, Savitz A, Emanuel J, Benz Jr EJ, Levenson R (1986) Rat-brain Na,K-ATPase beta-chain gene: primary structure, tissue-specific expression, and amplification in ouabain-resistant HeLa C+ cells. Mol Cell Biol 6:3884-3890.
Müller-Husmann G, Gloor S, Schachner M (1993) Functional characterization of $\beta$ isoforms of murine $\mathrm{Na}, \mathrm{K}$-ATPase: the adhesion molecule on glia (AMOG/ $\beta 2$ ), but not $\beta 1$, promotes neurite outgrowth. J Biol Chem 268:26260-26267.

Pagliusi S, Antonicek H, Gloor S, Frank R, Moos M, Schachner M (1989) Identification of a cDNA clone specific for the neural cell adhesion molecule AMOG. J Neurosci Res 22:113-119.

Pagliusi SR, Schachner M, Seeburg PH, Shivers BD (1990) The adhesion molecule on glia (AMOG) is widely expressed by astrocytes in developing and adult mouse brain. Eur J Neurosci 2:471-480.

Paladino T, Beesley PW, Nicholson S, Gurd JW (1990) Expression of the neuron-specific glycoprotein GP50 by granule cell cultures. Brain Res 521:131-137.

Peng L, Juurlink BHJ, Hertz L (1991) Differences in transmitter release, morphology, and ischemia-induced cell injury between cerebellar granule cell cultures developing in the presence and in the absence of a depolarizing potassium concentration. Dev Brain Res 63:1-12.

Pietrini G, Matteoli M, Banker G, Caplan MJ (1992) Isoforms of the $\mathrm{Na}, \mathrm{K}-\mathrm{ATPase}$ are present in both axons and dendrites of hippocampal neurons in culture. Proc Natl Acad Sci USA 89:8414-8418.

Schmalzing G, Kroner S, Schachner M, Gloor S (1992) The adhesion molecule on glia (AMOG/beta2) and alpha1 subunits assemble to functional sodium pumps in xenopus oocytes. J Biol Chem 267:20212-20216.

Schneider BG, Kraig E (1990) Na,K-ATPase of the photoreceptor: selective expression of alpha 3 and beta 2 isoforms. Exp Eye Res 51:553-564.

Schneider JW, Mercer RW, Gilmore-Hebert M, Utset MF, Lai C, Greene A, Benz EJ Jr (1988) Tissue specificity, localization in brain, and cell-free translation of mRNA encoding the A3 isoform of $\mathrm{Na}, \mathrm{K}$ ATPase. Proc Natl Acad Sci USA 85:284-288.

Shyjan AW, Gottardi C, Levenson R (1990) The Na,K-ATPase beta 2 subunit is expressed in rat brain and copurifies with Na,K-ATPase activity. J Biol Chem 265:5166-5169.

Stahl WL, Eakin TJ, Baskin DG (1993) Selection of oligonucleotide probes for detection of mRNA isoforms. J Histochem Cytochem 41:1735-1740.

Sun Y, Ball Jr WJ (1992) Determination of $\mathrm{Na}(+)-\mathrm{K}(+)$-ATPase alphaand beta-isoforms and kinetic properties in mammalian liver. Am $\mathbf{J}$ Physiol 262:C1491-C1499.

Sweadner KJ (1988) Preparation of the alpha(+) isozyme of the $\mathrm{Na}^{+}, \mathrm{K}^{+}$-ATPase from mammalian axolemma. Methods Enzymol 156:65-71.

Sweadner KJ, Gilkeson RC (1985) Two isozymes of the Na,K-ATPase have distinct antigenic determinants. J Biol Chem 260:9016-9022.

Sweadner KJ, Tang P, Arystarkhova EA, Peng L (1995) Na,K-ATPase $\beta$ subunit absence in astrocytes and C6 glioma. Soc Neurosci Abstr 21:583.

Therien AG, Nestor NB, Ball Jr WJ, Blostein R (1996) Tissue-specific versus isoform-specific differences in cation activation kinetics of the Na,K-ATPase. J Biol Chem 271:7104-7112.

Urayama O, Shutt H, Sweadner KJ (1989) Identification of three isozyme proteins of the catalytic subunit of the Na,K-ATPase in rat brain. J Biol Chem 264:8271-8280.

Watts AG, Sanchez-Watts G, Emanuel JR, Levenson R (1991) Cellspecific expression of mRNAs encoding $\mathrm{Na}^{+}, \mathrm{K}^{+}$-ATPase alpha- and beta-subunit isoforms within the rat central nervous system. Proc Natl Acad Sci USA 88:7425-7429. 